\title{
Memory-Related Synaptic Plasticity Is Sexually Dimorphic in Rodent Hippocampus
}

\author{
Weisheng Wang, ${ }^{1}$ Aliza A. Le, ${ }^{1}$ Bowen Hou, ${ }^{1}$ Julie C. Lauterborn, ${ }^{1}$ CConor D. Cox, ${ }^{1}$ Ellis R. Levin, $, 2,5$ Gary Lynch, ${ }^{1,3}$ \\ and ${ }^{-C h r i s t i n e ~ M . ~ G a l l ~}{ }^{1,4}$ \\ Departments of ${ }^{1}$ Anatomy and Neurobiology, ${ }^{2}$ Medicine, ${ }^{3}$ Psychiatry and Human Behavior, ${ }^{4}$ Neurobiology and Behavior, University of California, Irvine, \\ Irvine, California 92697, and 5Division of Endocrinology, Veterans Affairs Medical Center, Long Beach, California 90822
}

\begin{abstract}
Men are generally superior to women in remembering spatial relationships, whereas the reverse holds for semantic information, but the neurobiological bases for these differences are not understood. Here we describe striking sexual dimorphism in synaptic mechanisms of memory encoding in hippocampal field CA1, a region critical for spatial learning. Studies of acute hippocampal slices from adult rats and mice show that for excitatory Schaffer-commissural projections, the memory-related long-term potentiation (LTP) effect depends upon endogenous estrogen and membrane estrogen receptor $\alpha(\mathrm{ER} \alpha)$ in females but not in males; there was no evident involvement of nuclear ER $\alpha$ in females, or of ER $\beta$ or GPER1 (G-protein-coupled estrogen receptor 1) in either sex. Quantitative immunofluorescence showed that stimulation-induced activation of two LTP-related kinases (Src, ERK1/2), and of postsynaptic TrkB, required ER $\alpha$ in females only, and that postsynaptic ER $\alpha$ levels are higher in females than in males. Several downstream signaling events involved in LTP were comparable between the sexes. In contrast to endogenous estrogen effects, infused estradiol facilitated LTP and synaptic signaling in females via both ER $\alpha$ and ER $\beta$. The estrogen dependence of LTP in females was associated with a higher threshold for both inducing potentiation and acquiring spatial information. These results indicate that the observed sexual dimorphism in hippocampal LTP reflects differences in synaptic kinase activation, including both a weaker association with NMDA receptors and a greater ER $\alpha$-mediated kinase activation in response to locally produced estrogen in females. We propose that male/female differences in mechanisms and threshold for field CA1 LTP contribute to differences in encoding specific types of memories.
\end{abstract}

Key words: estrogen; estrogen receptor alpha; long-term potentiation; LTP; object location memory; TrkB

\section{Significance Statement}

There is good evidence for male/female differences in memory-related cognitive function, but the neurobiological basis for this sexual dimorphism is not understood. Here we describe sex differences in synaptic function in a brain area that is critical for learning spatial cues. Our results show that female rodents have higher synaptic levels of estrogen receptor $\alpha$ (ER $\alpha$ ) and, in contrast to males, require membrane $\mathrm{ER} \alpha$ for the activation of signaling kinases that support long-term potentiation (LTP), a form of synaptic plasticity thought to underlie learning. The additional requirement of estrogen signaling in females resulted in a higher threshold for both LTP and hippocampal field CA1-dependent spatial learning. These results describe a synaptic basis for sexual dimorphism in encoding spatial information.

\section{Introduction}

Much has been learned about synaptic mechanisms of memory encoding and the neuronal activity patterns that engage them.

Received March 20, 2018; revised June 22, 2018; accepted July 15, 2018.

Author contributions: W.W., A.A.L., J.C.L., C.D.C., E.R.L., G.L., and C.M.G. designed research; W.W., A.A.L., B.H., and J.C.L. performed research; W.W., A.A.L., B.H., J.C.L., C.D.C., G.L., and C.M.G. analyzed data; G.L. and C.M.G. wrote the paper.

This work was funded by National Institute of Neurological Disorders and Stroke Grants NS-045260 and NS085709 to G.L. and C.M.G., and Grant MH-101491 to G.L.; Grant 1101BX002316 from the Merit Review Award Program of the Department of Veterans Affairs to E.R.L.; and financial support from the University of California, Irvine, Center for Autism Research and Translation. We thank Dr. L.C. Palmer (University of California, Irvine) for comments on the manuscript.
This includes the particularly intriguing finding that memoryrelated long-term potentiation (LTP) of excitatory transmission in hippocampus (Vierk et al., 2012) and amygdala (Bender et al., 2017 ) is dependent upon locally synthesized estrogen in females but not in males. Hippocampal and other forebrain neurons express cytochrome p450 aromatase, the final enzyme in the pro-

The authors declare no competing financial interests.

Correspondence should be addressed to either Christine M. Gall or Gary Lynch, Department of Anatomy and Neurobiology, Gillespie Neuroscience Research Facility, 837 Health Science Road, University of California, Irvine, CA 92697, E-mail: cmgall@uci.edu or ga.s.lynch@gmail.com.

DOI:10.1523/JNEUROSCI.0801-18.2018

Copyright $\odot 2018$ the authors $\quad 0270-6474 / 18 / 387935-17 \$ 15.00 / 0$ 
duction of estradiol (E2), the most prevalent and potent estrogen in brain, and this enzyme is concentrated in hippocampal axon terminals in both sexes (Hojo et al., 2004, 2011; Kato et al., 2013; Tabatadze et al., 2014). Resultant E2 levels are substantially higher in hippocampus than in plasma, and, somewhat surprisingly, higher in males than in females (Mukai et al., 2010; Ooishi et al., 2012). Nevertheless, blocking local E2 production has been shown to eliminate LTP in females while having little if any effect on potentiation in males (Vierk et al., 2012; Bender et al., 2017). This is all the more surprising in that exogenous E2 applied at physiological concentrations is an extremely potent enhancer of glutamatergic transmission and hippocampal LTP in both sexes (Woolley, 2007; Kramár et al., 2009). These findings raise a number of fundamental questions concerning sex differences in the plasticity of excitatory synaptic transmission. Where in the complex signaling cascades that produce LTP does the neurosteroid exert its effects in females? Why do not the high levels of local estrogen in males contribute to LTP? And, regarding functional outcome, does the addition of an estrogen step in the production of enduring changes in synaptic strength in females affect the threshold levels of synaptic activity needed for inducing stable LTP, a point with evident implications for learning?

To address these issues the present studies first evaluated the type of estrogen receptor (ER) required for LTP of the glutamatergic, Schaffer-commissural (S-C) afferents to hippocampal field CA1 in adult female rats and mice. Although contributions of multiple ERs to synaptic responses have been described for hippocampal synapses (Smejkalova and Woolley, 2010; Kumar et al., 2015; Oberlander and Woolley, 2016), we anticipated this would be $\mathrm{ER} \beta$ because the infusion of agonists for this receptor enhances synaptic AMPA receptor responses and facilitates field CA1 LTP whereas ER $\alpha$ agonists do not (Kramár et al., 2009; Smejkalova and Woolley, 2010). However, the receptor critical for S-C LTP in females proved to be ER $\alpha$ and, more specifically, membrane-associated as opposed to nuclear $\operatorname{ER} \alpha$. Subsequent analyses identified an unexpected mode of action for ER $\alpha$ in females and, in particular, sexually dimorphic regulation of the NMDAR-regulated kinases Src, extracellular signal-regulated protein kinase $1 / 2($ Erk1/2), and tropomyosin receptor kinase B (TrkB), each of which play critical roles in consolidating newly induced LTP. The studies also identified markedly lower levels of synaptic $\mathrm{ER} \alpha$ in males compared with females, suggesting a reason why males do not use local estrogen to enhance plasticity.

The above results provided a neurobiological perspective from which to consider the much discussed question of sex differences in learning (Andreano and Cahill, 2009; Choleris et al., 2018). In in vivo studies of gonadally intact females, the problem is complicated by variations in levels of the circulating estrogen associated with phases of the estrous cycle. Using hippocampal slices from females, we found that infused E2, acting through both $\operatorname{ER} \alpha$ and $\operatorname{ER} \beta$, engages the same kinases activated by local estrogen through ER $\alpha$ during the induction of LTP and, further, that contributions of local estrogen offset a higher activity threshold for stable potentiation in females compared with males. Studies of field CA1-dependent spatial (object location) learning during the high versus low estrogen stages of the estrous cycle confirmed predictions from the LTP work regarding the activation of synaptic kinases and memory encoding.

\section{Materials and Methods}

Animals. Experiments were conducted using adult (2-4 months of age) rats and mice of both sexes that were group housed (four rats or five mice per cage) with food and water available ad libitum. All animals were on a
$12 \mathrm{~h}$ light/dark cycle. Experiments were initiated from 8:00 to 10:00 A.M. for electrophysiology and treatments for biochemical measures; animals were killed between 10:00 and 11:00 A.M. for studies involving immunofluorescence analysis alone. Animals were naive to treatment before the procedures described. Experiments were conducted in accordance with National Institutes of Health Guidelines for the Care and Use of Laboratory Animals, and protocols were approved by the University of California, Irvine, Institutional Care and Use Committee.

Estrous staging of female rats and mice. For all females used, estrous cycle state was evaluated using vaginal smears collected by lavage and Nissl staining (McLean et al., 2012). For electrophysiological studies, the estrous cycle state was determined from samples collected at the time of killing and was evaluated after the analysis of electrophysiological recordings. Results are reported separately for cases within proestrus (i.e., with smears showing a majority of large nucleated epithelial cells) compared with those outside proestrus, including estrus (showing clusters of cornified epithelial cells) and diestrus (many small darkly stained leukocytes and some cornified epithelial cells; McLean et al., 2012; Kato et al., 2013). As circulating estrogen levels are low in the latter states relative to proestrus (Kato et al., 2013), results for animals at these stages are presented together as "non-proestrus" for electrophysiological and signaling analyses. For behavioral experiments, vaginal smears were collected and evaluated by an independent investigator for several days before experimental use to select animals for training when in a specific estrous state. These animals were coded and run for behavioral analysis blind to that state.

Hippocampal slice electrophysiology. Extracellular field recordings were collected from hippocampal slices prepared from 40- to 50-d-old male and female Sprague Dawley rats (Harlan Laboratories) and 3- to 4-month-old male and female mice. The latter included mutants engineered to prevent trafficking of $\mathrm{ER} \alpha$ to the nucleus [i.e., membrane-only ER $\alpha$ (MOER) mice; Pedram et al., 2013] or to the plasma membrane [nucleus-only ER $\alpha$ (NOER) mice; Pedram et al., 2014] along with age-, sex-, and background strain (C57BL/6N)-matched wild-type (WT) mice for comparison. Some studies used conditional $\beta 1$-integrin knockouts (cKOs) and paired WTs (Wang et al., 2016a). The $\beta 1$ cKOs were generated by crossing mice homozygous for a floxed $\beta 1$-exon 3 with mice expressing Cre under control of the CaMKII promoter, thus generating progeny in which $\beta 1$ integrin expression was knocked down in excitatory hippocampal and cortical neurons beginning at $\sim 3$ weeks of age.

Acute hippocampal slices were prepared as described previously (Trieu et al., 2015; Wang et al., 2016b), collected into chilled highmagnesium artificial CSF (ACSF) containing the following (in mM): 124 $\mathrm{NaCl}, 3 \mathrm{KCl}, 1.25 \mathrm{KH}_{2} \mathrm{PO}_{4}, 5.0 \mathrm{MgSO}_{4}, 26 \mathrm{NaHCO}_{3}$, and 10 dextrose. Then the slices were transferred to an interface recording chamber at $31 \pm 1^{\circ} \mathrm{C}$ with $60-70 \mathrm{ml} / \mathrm{h}$ infusion of oxygenated ACSF containing the following (in mM): $124 \mathrm{NaCl}, 3 \mathrm{KCl}, 1.25 \mathrm{KH}_{2} \mathrm{PO}_{4}, 1.5 \mathrm{MgSO}_{4}, 26$ $\mathrm{NaHCO}_{3}, 2.5 \mathrm{CaCl}_{2}$, and 10 dextrose (Wang et al., 2016b). Experiments began $1.5 \mathrm{~h}$ after slice preparation. To study the responses of S-C innervation of field CA1b stratum radiatum (SR), stimulating electrodes were placed in CA1a and CA1c SR (Fig. 1) and a glass recording electrode $(2 \mathrm{M}$ $\mathrm{NaCl}$ filled, 2-3 M $\Omega$ ) was positioned in CAlb SR at the midpoint between the two stimulating electrodes; all electrodes were equidistant from the pyramidal cell layer (offset by $\sim 100 \mu \mathrm{m}$ ) to optimize recording responses to stimulation of the $\mathrm{S}-\mathrm{C}$ projection, which courses parallel to that cell layer. Stimulation intensity was set to elicit field EPSPs (fEPSPs) that were $50-60 \%$ of the maximum spike-free response. fEPSP initial slopes and peak amplitudes were measured using NACGather 2.0 (Theta Burst). With reagent infusion (e.g., ER $\alpha$ or ER $\beta$ antagonist), LTP was assessed within $30 \mathrm{~min}$ of infusion onset. Baseline stimulation was applied as single pulses at 3 pulses/min, and slices received experimental treatments after recording stable baseline responses for a minimum of 20 min. Unless otherwise specified, for electrophysiological studies LTP was induced with a single train of theta burst stimulation (TBS; 10 bursts of four pulses at $100 \mathrm{~Hz}$, with $200 \mathrm{~ms}$ between bursts; at baseline stimulation intensity) applied via one electrode. In abbreviated stimulation protocols, parameters of the individual stimulation bursts were the same, burst pairs and triplets were presented with $200 \mathrm{~ms}$ between the bursts, and there was a $2 \mathrm{~min}$ gap between sets (i.e., between pairs or triplets in the different protocols). In experiments involving TBS, control slices re- 

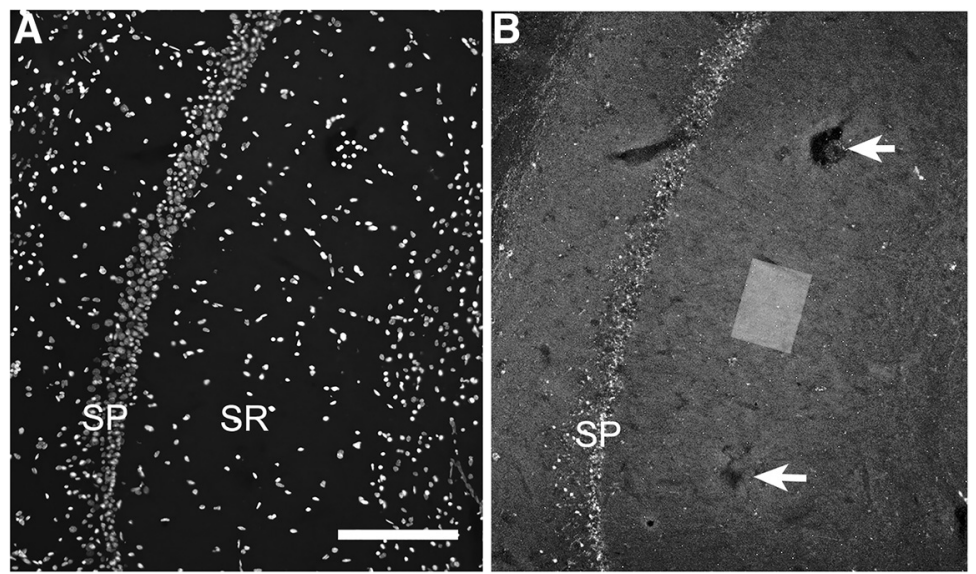

Figure 1. Electrode and image sample field placement in CA1SR. $\boldsymbol{A}, \boldsymbol{B}$, Images show at low-magnification, DAPI-labeled cellular nuclei $(\boldsymbol{A})$ and immunofluorescence $(\boldsymbol{B})$ for PSD-95 in the same CA1 field of a hippocampal slice to illustrate the position of the stimulating electrodes (arrows indicate areas of visible electrode damage) and of image $z$-stack collection (rectangle drawn to the scale of the sample field). In this case, the electrodes were lowered deep within the tissue to create visible damage for illustration purposes. SP, Stratum Pyramidale; SR, Stratum Radiatum. Scale bar: $\boldsymbol{A}$ (for $\boldsymbol{A}, \boldsymbol{B}), 200 \mu \mathrm{m}$.

ceived similarly placed low-frequency stimulation (LFS) of three pulses per minute. Group comparisons of the magnitude of LTP considered the mean response (fEPSP slope) during the last 5 min of electrophysiological recordings relative to baseline recordings. For immunofluorescence analyses of synaptic signaling associated with LTP, single 10 burst trains of TBS were applied to each of the two stimulating electrodes (Fig. 1), with $30 \mathrm{~s}$ between application of the first and second train.

Drug application. For hippocampal slice studies, antagonists were introduced to the ACSF perfusion line using a syringe pump, whereas E2 was added directly to the perfusion ACSF reservoir. The effects of vehicle (veh) and experimental reagent infusion were evaluated in parallel, on separate recording chambers, using slices from the same animal. The following reagents and final treatment concentrations were used: ER $\alpha$ antagonist methyl-piperidino-pyrazole (MPP; $3 \mu \mathrm{M}$ ); ER $\beta$ antagonist 4-[2-phenyl-5,7-bis(trifluoromethyl)pyrazolo[1,5- $\alpha$ ] pyrimidin-3-yl] phenol (PHTPP; $3 \mu \mathrm{M}) ; \beta$-E2 (1 nM); ANA-12 (750 nM); and rho-associated coiled-coil protein kinase (ROCK) inhibitor H1152 dihydrochloride (100 $\mathrm{nM}$ ), all from Tocris Bioscience; and selective G-protein-coupled ER (GPER1) antagonist G15 (500 nm; Cayman Chemical). For slice studies, all compounds were prepared in 100\% dimethylsulfoxide (DMSO) with the latter diluted to a final concentration in the ACSF bath of $<0.01 \%$ for both experimental and vehicle infusions. Echistatin (10 $\mu \mathrm{M}$; Sigma-Aldrich) was diluted in ACSF and applied locally by pressure ejection (Picospritzer, General Valve; Kramár et al., 2006). For electrophysiological analyses, the period of reagent infusion is indicated by a horizontal gray bar on the fEPSP plots. In particular, for LTP studies using ER $\alpha$ and ER $\beta$ antagonists, those compounds were infused beginning $30 \mathrm{~min}$ before until $10 \mathrm{~min}$ after TBS. For studies of the effects of hippocampal estrogen depletion, mice were given systemic injections of formestane $(2 \mathrm{mg} / \mathrm{kg}$, s.c.; Tocris Bioscience) daily for $7 \mathrm{~d}$ with the last treatment $1 \mathrm{~d}$ before experimental use. For behavioral experiments, mice were given intraperitoneal injections of the following drugs (or vehicle): MPP or PHTPP $(0.6 \mathrm{mg} / \mathrm{kg}, 60 \mathrm{~min}$ before behavior) dissolved in saline with 5\% DMSO (Labouesse et al., 2015; Li et al., 2017).

Immunostaining and fluorescence deconvolution tomography. Hippocampal slices were immersion fixed in $4 \%$ paraformaldehyde and sectioned at $20 \mu \mathrm{m}$, and then the slide mounted tissue sections were processed for dual immunofluorescence and fluorescence deconvolution tomography (FDT) as described previously (Rex et al., 2009; Babayan et al., 2012; Seese et al., 2013, 2014). Primary antisera cocktails included rabbit antisera to pTrkB Y515 (Wang et al., 2016a; 1:500; catalog \#NB10092656, Novus Biologicals; RRID:AB_1218205), the activated conformation of $\beta 1$ integrin (Wang et al., 2016a; 1:400; catalog \#MAB2259Z, EMD Millipore; RRID:AB_94616), pFAK Y397 (Bock and Herz, 2003; 1:500; catalog \#44-624G, ThermoFisher Scientific; RRID:AB_2533701), pCofilin Ser3 (Lauterborn et al., 2017; 1:500; catalog \#ab12866, Abcam; RRID:
AB_299488), pERK1/2 Thr202/Tyr204 (Seese et al., 2014; 1:500; catalog \#4370, Cell Signaling Technology; RRID:AB_2315112), phosphorylated (p) Src Tyr418 (Chen et al., 2010; 1:500; catalog \#44-660G, Thermo Fisher Scientific; RRID:AB_1500523), ER $\alpha$ (1:700; catalog \#sc542, Santa Cruz Biotechnology; RRID: AB_631470), or GPER1 (1:1000; catalog \#ab39742, Abcam; RRID:AB_1141090) in combination with mouse anti-postsynaptic density-95 [PSD95; 1:1000; catalog \#MA1-045, Thermo Fisher Scientific (RRID:AB_325399); or catalog \#ab12093, Abcam (RRID:AB_298846)], or mouse anti-ER $\beta$ (1:700; catalog \#sc-390243, Santa Cruz Biotechnology; RRID:AB_2728765) in combination with goat anti-PSD-95 (1:1000; catalog \#ab12093, Abcam; RRID:AB_298846). Secondary antisera included Alexa Fluor 594 anti-rabbit IgG with Alexa Fluor 488 anti-mouse IgG or anti-goat IgG, or Alexa Fluor 594 anti-mouse IgG with Alexa Fluor 488 anti-goat IgG (1:1000; Life Technologies).

For measures of synaptic immunolabeling, epifluorescence images were collected at $63 \times$ using a Leica DM6000B Microscope equipped with a Ludl stage with a BioPrecision Stepper motor driven by Volocity 4.0 software (PerkinElmer). Image $z$-stacks were collected in $200 \mathrm{~nm}$ steps through a depth of $2 \mu \mathrm{m}$ from CA1b SR for a total sample field of $136 \times 105 \times 2 \mu \mathrm{m}$ $\left(28,560 \mu \mathrm{m}^{3}\right)$. An individual $z$-stack was collected from CA1b SR from each of four to five tissue sections through each hippocampal slice. For image collection from slices having received S-C stimulation, the $z$-stack was collected from the mid-point between the positions of the two stimulation electrodes (evident by slight tissue damage) and at comparable distance from the cell layer (Fig. 1). Thus, the image-sample field was $\sim 200 \mu \mathrm{m}$ from each of the stimulation electrodes. The sample field was similarly placed (central CA1b SR) in slices that did not receive stimulation. In all cases, images were processed through restorative deconvolution (99\% confidence, Volocity 4.0$)$ and individual $z$-stacks were used to construct a three-dimensional (3D) montage of each sample field; within that field, objects were detected using threshold image segmentation across each channel separately. An image was normalized and thresholded at a given intensity threshold, erosion and dilation were used to fill holes and remove background pixels, and objects were segmented based on connected pixels above a threshold using in-house software (using C, Java, Matlab, and Perl). All immunofluorescent elements meeting size constraints of synapses, and detected across multiple intensity thresholds, were quantified using automated systems (Rex et al., 2009; Babayan et al., 2012; Seese et al., 2014; Wang et al., 2016a); objects that were not detected at multiple thresholds were not counted as these likely represent artifacts (Babayan et al., 2012). The PSD-95-immunoreactive (IR) elements were considered to be double labeled for the second antigen if there was contact or overlap in fields of the two fluorophores as assessed in 3D. These procedures result in the analysis of $\sim 30,000$ reconstructed PSD-95-IR elements (i.e., PSDs) per sample field and $>100,000$ PSDs per slice. Using this approach, we have been able to quantify treatment effects on signaling proteins that are restricted to the presynaptic or postsynaptic compartment with the induction of LTP (Chen et al., 2010; Wang et al., 2018).

The quantification of synaptic immunolabeling is presented graphically in two ways. First, using automated systems, the density of immunoreactivity to the antigen colocalized with PSD-95 was measured for each double-labeled PSD, and the numbers of such elements within a particular density range were expressed as a percentage of all doublelabeled PSDs (i.e., double-labeled, PSD-95-IR elements) within the full $28,560 \mu \mathrm{m}^{3}$ sample field. These results were used to construct line graph, immunolabeling density frequency distributions wherein elements with lower levels of immunoreactivity (e.g., for pSrc) are plotted toward the left and those with dense immunoreactivity are plotted toward the right on the $x$-axis; for these data, significance was determined using repeated- 
measures (RM) ANOVA. Second, to provide an index of the proportion of PSD-95-IR synapses densely labeled for the second antigen, bar graphs show the numbers of synapses for which immunolabeling for the second antigen was at and above a specific density threshold (in all analyses, immunfluorescence density of $\geq 90$ ) normalized to the control group (vehicle or LFS) mean for that particular experiment; for these analyses, significance was determined using a two-tailed $t$ test (two groups) or one-way ANOVA followed by post hoc comparisons (three or more groups). In all cases, group mean \pm SEM values are shown.

To illustrate the synaptic localization of $\operatorname{ER} \alpha$, image $z$-stacks of dual $\mathrm{ER} \alpha$ and PSD-95 immunolabeling (in tissue processed as described above) were recorded using a ThorLabs two-photon microscope, and 1.4 numerical aperture, $63 \times$ objective $z$-stacks were collected at the Nyquist rate $(0.13 \mu \mathrm{m}$ steps through a depth of $2 \mu \mathrm{m})$. Stacks were deconvolved using AutoQuant version 2.2.1 (Media Cybernetics) and constructed into a 3D montage using Imaris (Bitplane; Lauterborn et al., 2016).

Object location memory. As detailed previously (Seese et al., 2014), C57BL/6J mice at 8-10 weeks of age were handled for 2 min daily for $5 \mathrm{~d}$ and then habituated to a white $(24 \times 30 \times 30 \mathrm{~cm})$ Plexiglas chamber for $5 \mathrm{~min} / \mathrm{d}$ for at least $5 \mathrm{~d}$. For the training trial the following day, mice were placed in the chamber containing identical small glass funnels in two adjacent corners of the apparatus for 5 or $10 \mathrm{~min}$. For retention testing, mice were returned to the chamber $24 \mathrm{~h}$ post-training, with either the left or right funnel being displaced toward the chamber center, and were allowed to explore for $5 \mathrm{~min}$. Animal movements within the chamber were video recorded using an overhead camera for all training and test sessions. Movements were scored from the videos by an observer who was blind to experimental group and treatment. Object exploration was scored in seconds when the animal was facing toward and sniffing the object (funnel) within $\sim 0.5 \mathrm{~cm}$. Interaction was not scored when the animal climbed over the object or when they were within the zone but not addressing the objects (i.e., turning head). Discrimination index (DI) was calculated as $100 \times\left(t_{\text {novel }}-t_{\text {familiar }}\right) /\left(t_{\text {novel }}+t_{\text {familiar }}\right)$ and total object exploration time was the total sum time of interactions with both objects.

Experimental design and statistical analyses. Execution of experimental procedures and analyses were arranged to enhance rigor and avoid experimenter bias. Specifically, for analyses of electrophysiological responses in NOER and MOER mice, hippocampal slices from agematched mutant and wild-type mice were run simultaneously on parallel electrophysiology rigs using the same ACSF and reagent solutions. For studies of the effects of sex and estrogen receptor antagonism on synaptic signaling, acute hippocampal slices from the same animal were run on parallel rigs to first assess the effect of the test reagent (e.g., MPP, rig 1) versus vehicle (rig 2) on synaptic responses in the same animal. The slices were then fixed and processed for immunostaining in batches that included groups to be compared for that particular analysis (e.g., male vs female, with MPP vs without MPP). Immunofluorescent labeling was photographed blind to group, and the quantification of synaptic labeling was accomplished using automated systems that avoid the potential effects of experimenter bias.

Group sizes for the different analyses were selected on the basis of past experience and to be equal to or exceed the dictates of power analyses. For electrophysiological studies, power analysis determined that with the typical effect size and profile (i.e., LTP magnitude entailing a 50\% increase in fEPSP slope; $\sigma=15 ; \alpha=0.05$; power $=0.80$ ) the minimal sample size to determine the significance of a $20 \%$ change in LTP magnitude would be five slices/group. For immunofluorescence analyses, the power analysis determined that, for typical effect sizes from similar studies (Wang et al., 2016a), we needed an " $n$ " of at least four slices/group. For behavior experiments, similar calculations determined with an effect size (i.e., DI) of $30 \%(\sigma=10 \% ; \alpha=0.05$; power $=0.80)$ that the minimal sample size to detect a $10 \%$ difference in the DI would be three per group. As to exclusions, no animals were excluded from analysis in behavioral studies. For immunofluorescence, in rare instances where measures from an individual tissue section appeared to be strikingly different from others in that set, we constructed immunofluorescence cumulative density distributions and would exclude the section from analysis if the initial slope of that distribution was $\geq 4$ SDs from the mean slope for all other sections in that treatment group. No electrophysiological results (for individual animals or slices) were dropped. Throughout the text, $n$ values denote the numbers of hippocampal slices per group unless otherwise indicated. For electrophysiological studies, slices were obtained from four or more animals. For behavioral experiments, the analyses of movements were made from video recordings by an investigator blind to estrous cycle state and experimental group.

The results are presented as group mean \pm SEM values. Statistical significance (i.e., $p \leq 0.05$ ) was evaluated using a two-tailed Student's $t$ test unless otherwise specified; some experiments used one- and two-way ANOVA (GraphPad Prism, GraphPad Software ) as indicated. In graphs, asterisks denote the level of significance $\left({ }^{*} p \leq 0.05 ;{ }^{* *} p \leq 0.01 ;{ }^{* *} p \leq\right.$ $0.001)$.

\section{Results}

\section{LTP consolidation in female CA1 requires endogenous estrogen acting on membrane ER $\alpha$}

Prior work had shown that in rats the depletion of estrogen levels using the aromatase inhibitor letrozole, given in vivo in several daily systemic injections before acute slice preparation or in bath treatments of cultured hippocampal slices, impairs LTP in the $\mathrm{S}-\mathrm{C}$ projections to field CA1 of females but not males (Vierk et al., 2012). We tested for similar sex-specific effects of estrogen depletion on TBS-induced S-C LTP in mice using in vivo pretreatment (seven daily intraperitoneal injections) with the structurally different aromatase inhibitor formestane (Wei et al., 2014). In acute hippocampal slices from formestane-pretreated female mice, TBS applied to the S-C projections elicited normal initial potentiation but this failed to stabilize, with responses decaying to control levels over the hour post-TBS; in contrast, potentiation in females pretreated with vehicle was stable and robust (Fig. $2 \mathrm{~A}$, left). The infusion of $1 \mathrm{nM}$ E2 largely restored LTP in slices from formestane-pretreated female mice (Fig. $2 A$, right). Formestane pretreatment had no effect on $S-C$ potentiation in slices from males $\left(p=0.69, t_{(14)}=0.41\right.$; veh, $n=7$; formestane, $\left.n=9\right)$. Together with prior results, these experiments demonstrate that in females, but not in males, field CA1 LTP is dependent upon local estrogen action.

Next, we used selective receptor antagonists to evaluate which of the principle ERs expressed in hippocampus $(\mathrm{ER} \alpha, \mathrm{ER} \beta$, and GPER1; Hara et al., 2015) mediates the effects of endogenous estrogen on LTP. Infusion of the ER $\alpha$ antagonist MPP (3 $\mu \mathrm{M})$ markedly reduced S-C potentiation in slices from females, but not males (Fig. 2B). Bath treatment with antagonists for ER $\beta$ (PHTPP, $3 \mu \mathrm{M}$ ) or the third ER in hippocampus GPER1 (Almey et al., 2015; Kumar et al., 2015; Waters et al., 2015; G15, 500 nM) had no effect on LTP in females (Fig. $2 C, D$ ). Similarly, PHTPP infusion had no effect on S-C LTP in males $\left(p=0.74, t_{(14)}=0.23\right.$, $n=8$ /group); this despite the finding that $\mathrm{E} 2$ infusion both facilitates LTP and enhances baseline synaptic transmission in males via $\operatorname{ER} \beta$ (Kramár et al., 2009; Wang et al., 2016a). We conclude that the effects of local estrogen on LTP depends on ER $\alpha$ in females only.

In slices from females, the composite response to the first theta burst in a train (Fig. 2E) and the well known within-train facilitation of burst responses (Kramár et al., 2009; Fig. 2F) were comparable to responses in slices from males and, similarly, were not affected by MPP treatment. Within-train facilitation reflects the suppression of feedforward IPSPs and associated increases in NMDAR-mediated depolarization (Larson and Lynch, 1986). Thus, these findings indicate that the initial triggering steps for LTP are similar in CA1 of males and females and are not influenced by estrogen acting through $\mathrm{ER} \alpha$. Note also that the initial S-C potentiation produced by TBS, a variable that is strongly dependent on NMDARs (Larson and Lynch, 1986), 

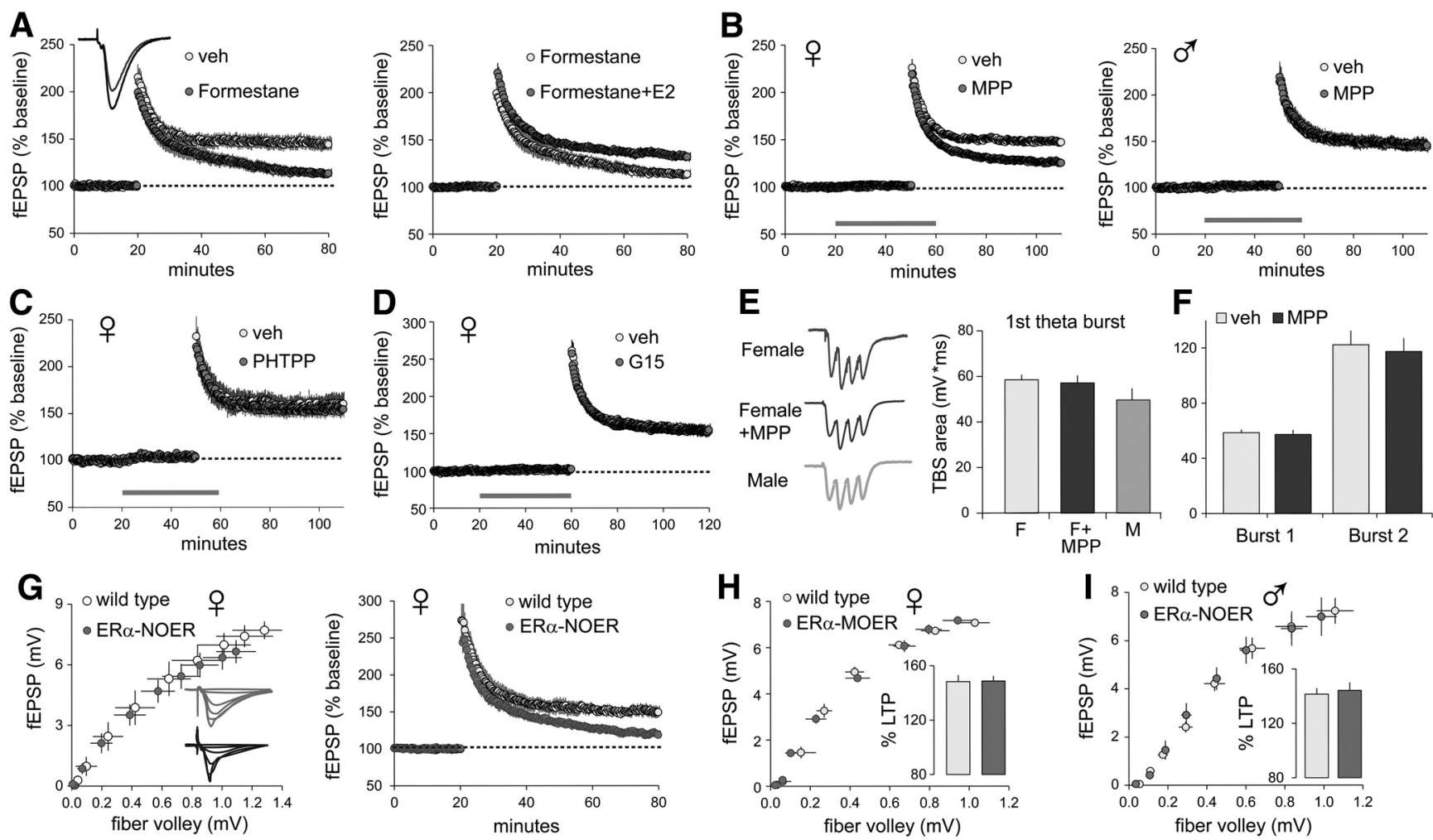

Figure 2. Local estrogen promotes LTP via membrane ER $\alpha$ in female hippocampus. LTP was induced by TBS of S-C projections, and fEPSPs were recorded from CA1 SR; in this and subsequent illustrations, periods of reagent infusion are indicated by a horizontal gray line on the fEPSP plot. $A$, Left, In vivo formestane pretreatment severely impaired LTP in slices from female rats $\left(p=0.0026, t_{(10)}=3.98\right.$ for veh vs formestane during the last 5 min of recordings; $n=6 /$ group). Right, E2 (1 nM) perfusion initiated 30 min before TBS rescued LTP in slices from formestane-pretreated females ( $p=0.017, t_{(17)}=2.65$; formestane, $n=6$; formestane $+E 2, n=13) \cdot B$, ER $\alpha$ antagonistMPP blockedLTPinfemaleslices (left; $p<0.0001, t_{(26)}=5.55 ; n=14 /$ group) butnotmaleslices (right; $p=0.87, t_{(16)}=0.16, n=9 /$ group). $\boldsymbol{C}, \boldsymbol{D}$, Neither ER $\beta$ antagonist PHTPP $\left(\boldsymbol{C} ; p=0.70, t_{(10)}=0.39 ; n=6 /\right.$ group) nor GPER1 antagonist G15 ( $\boldsymbol{D} ; p=0.84, t_{(17)}=0.21 ;$ veh, $\left.n=10 ; \mathbf{G} 15, n=9\right)$ influenced S-CLTP in females. $\boldsymbol{E}$, The size (area) of the first theta burst response was not different among female, female $+\mathrm{MPP}$, or male slices $\left(p=0.20, F_{(2,26)}=1.70\right.$, one-way ANOVA; male, $n=7 ;$ other groups, $\left.n=10\right)$. $\boldsymbol{F}, \mathrm{MPP}$ did not influence the theta burst response enhancement between the first and second burst in females ( $p=0.77, F_{(1,18)}=0.09$, two-way ANOVA; $n=10 /$ group). G, The fiber volley-to-fEPSP amplitude relationship (I/0 curve) for female NOER mice was comparable to that of female WTs $\left(p=0.61, F_{(9,90)}=0.81\right.$, two-way ANOVA; $n=6 /$ group) but S-CLTP failed to stabilize $\left(p=0.0006, t_{(14)}=4.39\right.$ vs WT; WT, $n=6 ;$ NOER, $\left.n=10\right) . \boldsymbol{H}$, For female MOER mice, both the I/0 curve $\left(p=0.21, F_{(8,144)}=1.37\right.$, two-way RM ANOVA; WT, $n=10 ;$ MOER, $\left.n=12\right)$ and S-CLTP (inset bar graph; LTP expressed as percentage baseline, $p=0.99, t_{(20)}=0.01$; WT, $n=10 ;$ MOER, $n=12$ ) were comparable to measures from female WTs. I, For male NOER mice, both the I/0 curve $\left(p=0.93, F_{(7,77)}=0.36\right.$, two-way ANOVA; WT, $n=7$; NOER, $\left.n=6\right)$ and S-CLTP (inset bar graph, $p=0.77, t_{(23)}=0.30 ; \mathrm{WT}, n=9 ; \mathrm{NOER}, n=16$ ) were comparable to measures from male WTs.

was comparable in males and females and was unaffected by MPP (Fig. 2B).

To further test the conclusion that ER $\alpha$ is critical for S-C LTP in adult females, we assessed potentiation in transgenic mice selectively lacking either membrane or nuclear variants of the receptor. NOER mice have a point mutation that prevents $\mathrm{ER} \alpha$ palmitoylation and, as a consequence, plasma membrane trafficking (Pedram et al., 2014). The mutants have impaired reproductive tract development like full ER $\alpha$ knockouts (Pedram et al., 2014), but hippocampal structure and basic synaptic physiology are normal. Input/output (I/O) curves for fEPSPs were comparable for slices from NOER and WT female mice (Fig. 2G, left). However, despite normal initial potentiation, LTP failed to stabilize in female NOER mice (Fig. $2 G$, right). In contrast, in slices from female mice that express the membrane-associated ER $\alpha$, but lack nuclear ER $\alpha$ (MOER mice; Pedram et al., 2013), the S-C I/O curve and LTP were normal (Fig. 2H). In distinction from females, male NOER mice were indistinguishable from WTs with regard to both the S-C I/O curve and LTP (Fig. $2 I$ ). These results reinforce the conclusion that $\mathrm{ER} \alpha$ is needed for LTP in female, but not male, hippocampal field CA1 and further show that nuclear $\mathrm{ER} \alpha$ does not contribute to the I/O curve or to LTP in either sex.
Females require ER $\alpha$ for TBS activation of synaptic kinases critical for LTP

Activation of synaptic NMDARs is already evident on the second burst in a TBS train, and this is among the first steps in the induction of S-C LTP (Lynch et al., 2013). This is quickly followed by NMDAR-dependent activation of postsynaptic kinases including the Src family kinases (Src; Chen et al., 2010) and ERK1/2 (Wang et al., 2007; El Gaamouch et al., 2012). Src kinases then phosphorylate the cytoplasmic tail of NMDAR subunit NR2B, further increasing calcium influx (Salter and Kalia, 2004; Trepanier et al., 2012). These secondary signaling events support LTP stabilization and memory formation (Lu et al., 1998; Giovannini et al., 2001; Bozon et al., 2003; Giovannini, 2006; Yamazaki et al., 2006; Patterson et al., 2010) and, for Src, promote activation of other synaptic receptors required for LTP stabilization including the neurotrophin receptor TrkB (Chen et al., 2010) and $\beta 1$ integrins (Babayan et al., 2012; Wang et al., 2016a). Membrane ER $\alpha$ signals to both Src and ERK1/2 in various cell types including neurons (Song et al., 2005; Fu and Simoncini, 2008; Micevych et al., 2017). We therefore used immunofluorescence to test whether ER $\alpha$ modulates TBS-driven increases in synaptic Src and ERK1/2 phosphorylation at specific activation sites in hippocampal slices from male and female rats. Dual im- 
A

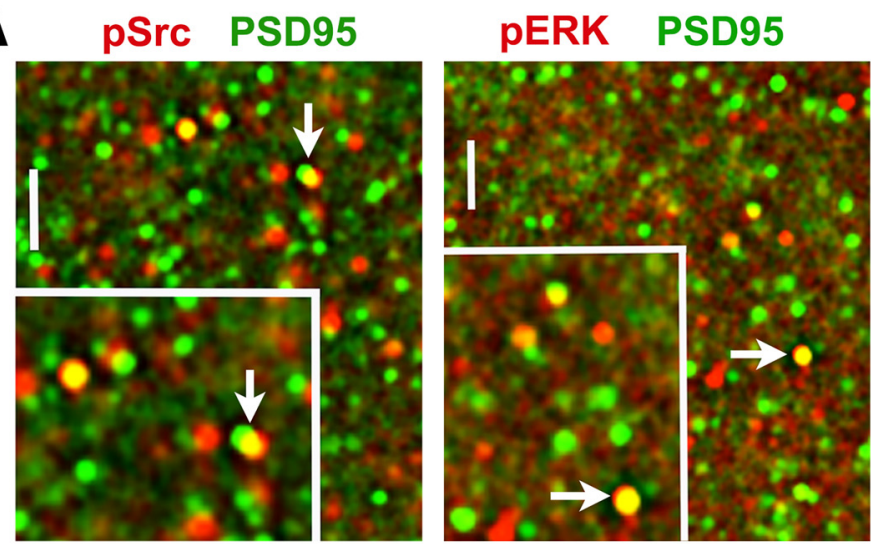

B

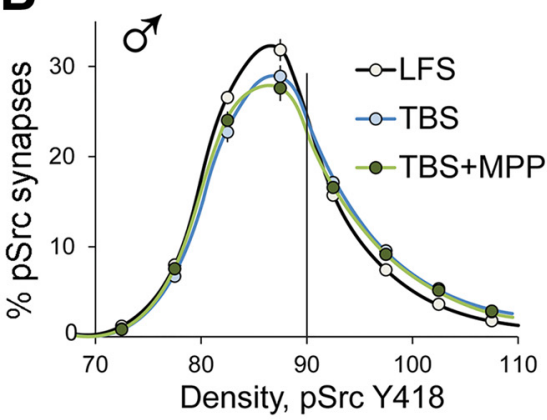

C

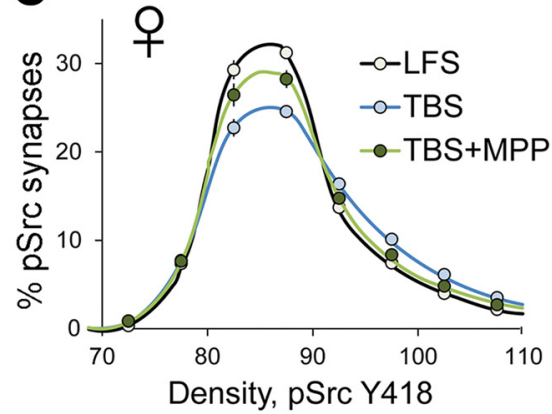

D

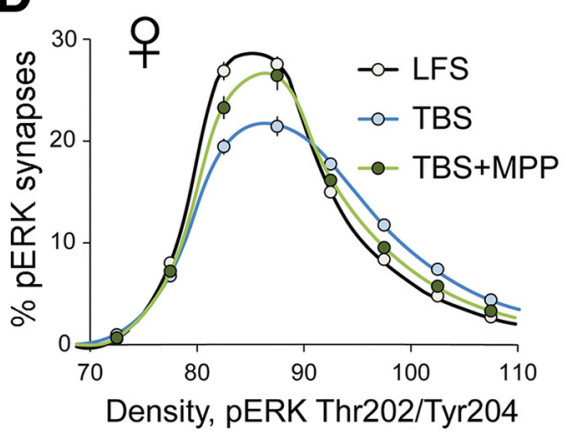

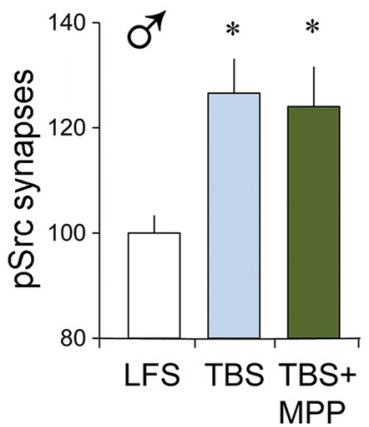
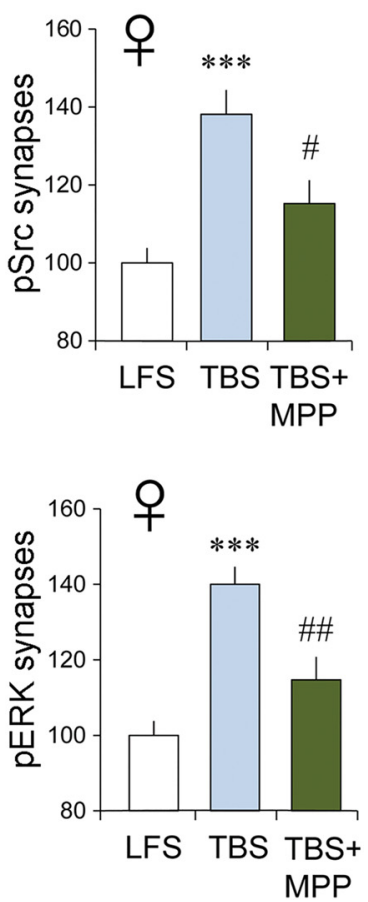

Figure 3. TBS-driven increases in synaptic pSrc and pERK are ER $\alpha$ dependent in females. Fluorescence deconvolution tomography was used to assess the effects of $S$-C stimulation on synaptic immunolabeling at 3-4 min post-TBS. Line graphs show immunolabeling density frequency distributions for the phosphoprotein at all double-labeled (phosphoprotein-IR + PSD-95-IR) synapses (see Materials and Methods); treatment effects on frequency distributions were assessed using two-way RM ANOVA. Bar graphs show the proportion of double-labeled synapses containing dense immunolabeling for the phosphoprotein ( $\geq 90$ density units) with group mean values normalized to the mean for control (LFS) slices. $\boldsymbol{A}$, Deconvolved images show punctate localization of PSD-95-IR (green) in combination with that for pSrc (red, left) and pERK1/2 (red, right); yellow indicates double-labeled elements (arrows). Scale bar: large image, $10 \mu \mathrm{m}$; inset, $2 \mu \mathrm{m}$. B, In slices from males, TBS caused a greater rightward skew in the pSrc density frequency distribution (thus, an increase in the proportion of synapses with dense $\mathrm{pSrc}$ immunoreactivity) compared with the curve for slices receiving LFS $\left(p<0.0001, F_{(19,323)}=5.348 ; \mathrm{LFS}, n=9 ; \mathrm{TBS}, n=10\right.$; TBS + MPP, $\left.n=10\right)$; this effect was not influenced by ER $\alpha$ antagonist MPP $\left(p=0.917, F_{(19,342)}=0.585\right)$. Bar graph shows that in males TBS increased the

munofluorescence and FDT were used to generate digital 3D reconstructions of synapses immunolabeled for the target phosphoprotein and the excitatory synapse protein PSD-95 (Petersen et al., 2003) in the CA1b field surrounding the recording electrode (Fig. 3A). FDT supports the quantification of $>30,000$ double-labeled synapses per $136 \times 105 \times$ $2 \mu \mathrm{m}$ image $z$-stack and $>100,000$ synapses per hippocampal slice (Rex et al., 2009; Babayan et al., 2012; Seese et al., 2012), and the discrete localization of protein modifications to presynaptic versus postsynaptic compartments (Chen et al., 2010; Wang et al., 2018). We first confirmed the finding (Chen et al., 2010) that a single TBS train increases the proportion of PSDs associated with dense concentrations of pSrc Y418 in male field CA1: in slices receiving TBS, compared with those receiving LFS, the density frequency distribution for pSrc immunoreactivity colocalized with PSD-95 exhibited a greater skew to the right (Fig. 3B, left), and the proportion of double-labeled synapses containing high levels of pSrc immunoreactivity ( $\geq 90$ units on the frequency distribution) was greater (Fig. 3B, right). Infusion of the $\mathrm{ER} \alpha$ blocker MPP did not attenuate either effect in males (Fig. $3 B$ ) and the ER $\beta$ antagonist PHTPP was also ineffective (data not shown; $p>$ $0.999, F_{(19,418)}=0.113, n=12$ /group for frequency distributions in TBS vs TBS + PHTPP groups).

Strikingly different results were obtained with slices from young adult females. For the CA1 SR recording field, TBS increased both the rightward skew in

$\leftarrow$

numbers of PSD-95-IR synapses with dense pSrc immunolabeling relative to measures from slices receiving LFS and that this effect was not altered by $\operatorname{MPP}\left(p=0.0135, F_{(2,28)}=5.11\right.$, Bonferroni's test for post hoc comparisons; LFS vs TBS, ${ }^{*} p<$ $0.05 ;$ LFS vs TBS + MPP, ${ }^{*} p<0.05 ;$ TBS vs TBS + MPP, n.s. $)$. $C$, In females, TBS also caused a greater rightward skew in the pSrc immunolabeling density frequency distribution relative to that for LFS slices (left; $p<0.0001, F_{(19,342)}=24.56 ; n=$ 10/group); MPP substantially reduced this effect $(p<0.0001$, $\left.F_{(19.342)}=5.981\right)$. The bar graph shows that in females the proportion of PSDs with dense pSrc-IR was increased by TBS and that this increase was substantially reduced by $\operatorname{MPP}(p=$ $0.0002, F_{(2,29)}=12.33$; post-test: LFS vs TBS, $p<0.001$; TBS vs TBS + MPP, \#p $<0.02$; LFS vs TBS + MPP, n.s.). D, TBS caused a greater rightward skew in the density frequency distribution for synaptic pERK-IR in female slices $(p<0.0001$, $F_{(19,361)}=34.62 ; \mathrm{LFS}, n=10 ; \mathrm{TBS}, n=11 ; \mathrm{TBS}+\mathrm{MPP}$, $n=8)$; MPP substantially reduced this effect $(p<0.0001$, $\left.F_{(19,323)}=10.01\right)$; bar graph shows that the TBS-driven increase in the numbers of densely $p$ ERK-IR synapses was similar in magnitude to that for pSrc and attenuated by MPP ( $p<$ $0.0001, F_{(2,28)}=19.68 ;$ LFS vs TBS, ${ }^{* * *} p<0.0001 ;$ TBS vs $\mathrm{TBS}+\mathrm{MPP}, \# \# p<0.01)$. 
A
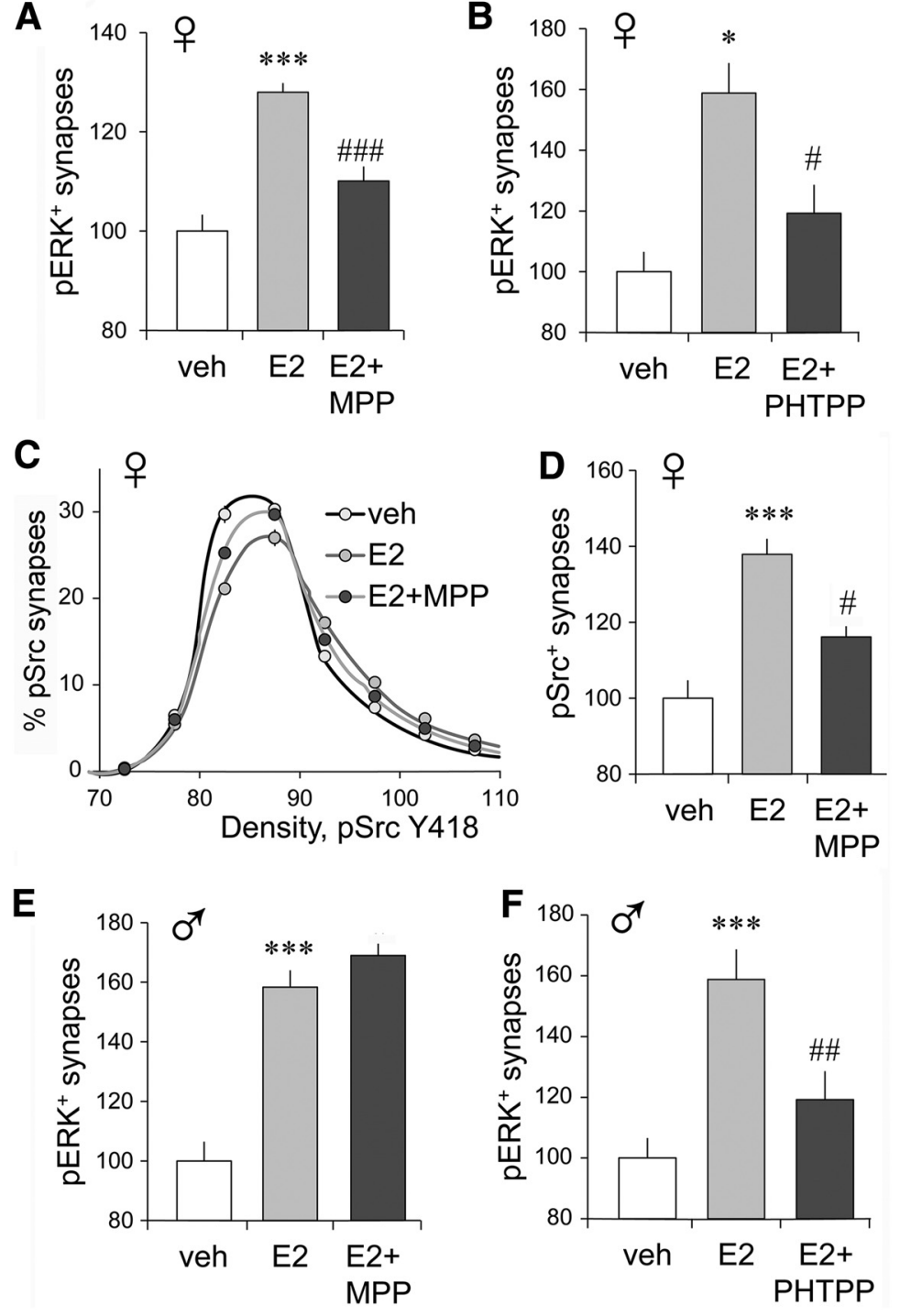

Figure 4. E2 infusion increases synaptic ERK1/2 and Src phosphorylation. $A$, E2 perfusion alone increased the percentage of synapses with dense concentrations of synaptic PERK1/2-IR in female slices relative to veh treatment; the effect was reduced by $\operatorname{MPP}\left(p<0.0001, F_{(2,35)}=26.21\right.$; post hoc tests: veh vs E2, ${ }^{* * *} p<0.0001$; E2 vs E2 + MPP, \#\#\# $<0.001 ; n=10 /$ group; quantitative FDT analysis). $B$, Additional experiments confirmed that E2 increased synaptic $P E R K 1 / 2-I R$ and further showed that the ER $\beta$ antagonist PHTPP reduced the effect $\left(p=0.0002, F_{(2,28)}=12.27\right.$; posthoctests: veh vs E2, ${ }^{*} p<0.05$; E2 vs E2 + PHTPP, $\# p<0.05 ;$ veh, $n=10 ; \mathrm{E} 2$ and E2 + PHTPP. $n=11) . C$, E2 increased the rightward skew in the density frequency distribution for pSrc-IR colocalized with PSD-95 (vs vehicle, $\left.p<0.0001, F_{(19,418)}=33.42\right)$; MPP blocked most of this effect $\left(p<0.0001, F_{(19,418)}=\right.$ $12.32 ; n=12$ /group). $\boldsymbol{D}$, E2 treatment of female slices produced the predicted, MPP-sensitive increase in the proportion of doubled-labeled synapses with dense $p S r c-I R$ relative to vehicle controls $\left(p=0.0002, F_{(2,29)}=12.33\right.$; Bonferroni's post-test: veh vs $E 2$, ${ }^{* * *} p<0.0001 ; E 2$ vs $E 2+M P P$, \#p $<0.05 ; n=12$ /group). $E$, In male slices, E2 infusion increased the percentage of synapses with dense $\mathrm{PERK} 1 / 2-\mathrm{IR}$, but the increase was not affected by $\operatorname{MPP}\left(p<0.0001, F_{(2,29)}=37.51\right.$; post hoc tests: veh vs E2, ${ }^{* * *} p<0.001 ; \mathrm{E} 2$ vs $\mathrm{E} 2+\mathrm{MPP}, \# p>0.05 ; n=10$ /group). $\boldsymbol{F}$, Separate experiments replicated the E2-induced increase in synaptic pERK1/2 in male slices and determined that this was suppressed in the presence of PHTPP $\left(p=0.0002, F_{(2,26)}=12.27\right.$; post hoc tests: veh vs E2, ${ }^{* * *} p=0.0001 ; \mathrm{E2}$ vs E2 + PHTPP, \#\# $=0.01$; veh and E2, $n=10 ; \mathrm{E} 2+\mathrm{PHTPP}, n=9$ ).

the pSrc density frequency distribution (Fig. $3 C$, left) and the percentage of PSDs with high concentrations of pSrc immunoreactivity (Fig. 3C, right); in contrast to results in males, the ER $\alpha$ antagonist MPP significantly reduced both effects in females. As previously reported for males, TBS causes a robust increase in synaptic pERK1/2 Thr202/Tyr204 (Seese et al., 2012). This effect of TBS was also present in slices from females but was markedly reduced by MPP (Fig. $3 A, D$ ). Thus, two early NMDAR-dependent steps in the production of S-C LTP require $\mathrm{ER} \alpha$ function in females but not in males.
Sexually dimorphic effects of infused estradiol on synaptic kinase activation The essential contribution of ER $\alpha$ to LTP in females (but not males) could involve the facilitation of NMDAR-gated synaptic currents or a direct action of ER $\alpha$ on Src and ERK1/2. As described above (Fig. $2 E, F)$, the $\mathrm{ER} \alpha$ antagonist MPP, infused beginning $30 \mathrm{~min}$ before TBS, had no detectable effect on the NMDAR-mediated within-train increase in the size of the composite fEPSP response, an observation that argues against an influence of $\mathrm{ER} \alpha$ on NMDAR function during the induction of LTP. Estrogen receptors signal directly to both ERK1/2 and Src in various cell preparations (Fu and Simoncini, 2008), and we found that bath perfusion of 1 nM E2 rapidly increased phosphorylation of synaptic ERK1/2 in hippocampal slices from females, as evidenced by an increase in the percentage of PSD-95-IR synapses associated with high concentrations of pERK1/2. This effect was substantially reduced by either $\mathrm{ER} \alpha$ blocker MPP (Fig. $4 A$ ) or ER $\beta$ blocker PHTPP (Fig. 4B). Similar results were obtained for pSrc: in female slices, E2 infusion and increased the rightward skew in the density frequency distribution for synaptic pSrc immunoreactivity (Fig. 4C) and increased the proportion of PSDs associated with dense pSrc immunoreactivity (Fig. $4 D$ ); both of these effects were significantly attenuated by ER $\alpha$ antagonist MPP (Fig. $4 C, D)$. These results confirm that in females E2 acting through $\mathrm{ER} \alpha$ directly promotes intermediary steps (kinase activation) between the NMDARs and the actin remodeling that underlies LTP (Lynch et al., 2013) at hippocampal synapses. The results further show that in contrast to the effects of endogenous estrogen, in females infused E2 influences these kinases through both $\mathrm{ER} \alpha$ and $\mathrm{ER} \beta$.

We tested for similar regulation of the synaptic kinases in slices from male rats and found that E2 infusion robustly increased the proportion of PSD-95-IR excitatory synapses with dense pERK1/2 immunoreactivity, but in contrast to effects in females, this increase was not influenced by the ER $\alpha$ blocker MPP (Fig. $4 E$ ). In males, the ER $\beta$ antagonist PHTPP reduced E2-driven increases in synaptic pERK1/2 (Fig. 4F). This result aligns with our previous observation that $\mathrm{ER} \beta$ is critical for LTP enhancement by exogenous E2 in male hippocampus with negligible contribution from $\mathrm{ER} \alpha$ (Kramár et al., 2009).

\section{Synaptic ER $\alpha$ concentrations are higher in females than males}

The preceding results provide evidence that exogenous and local estrogens both activate synaptic kinases via ER $\alpha$-dependent 

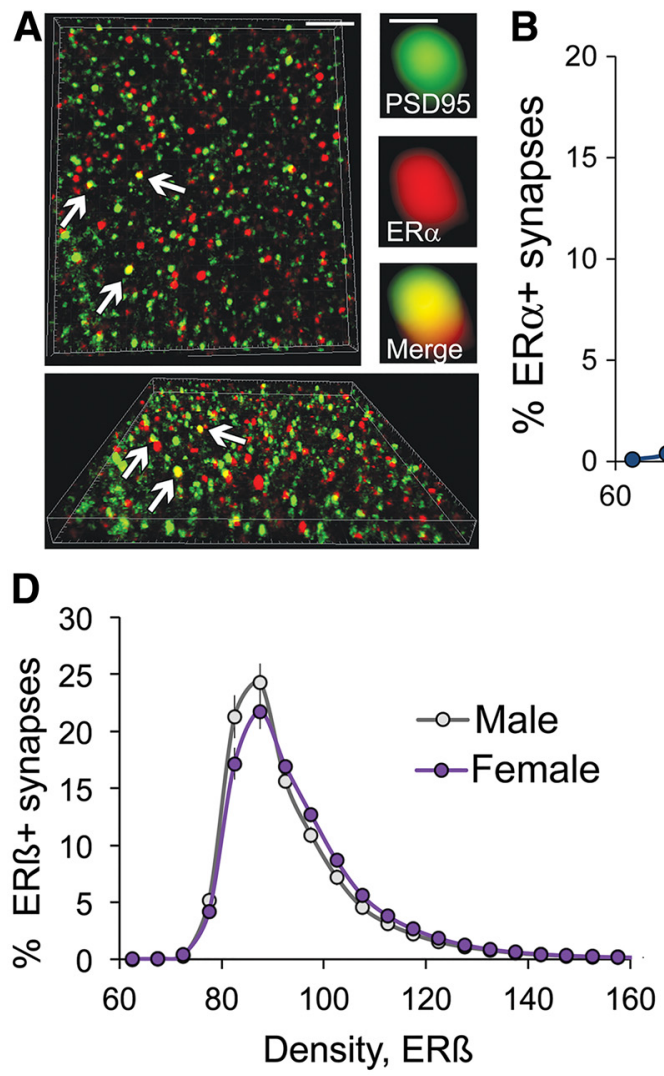
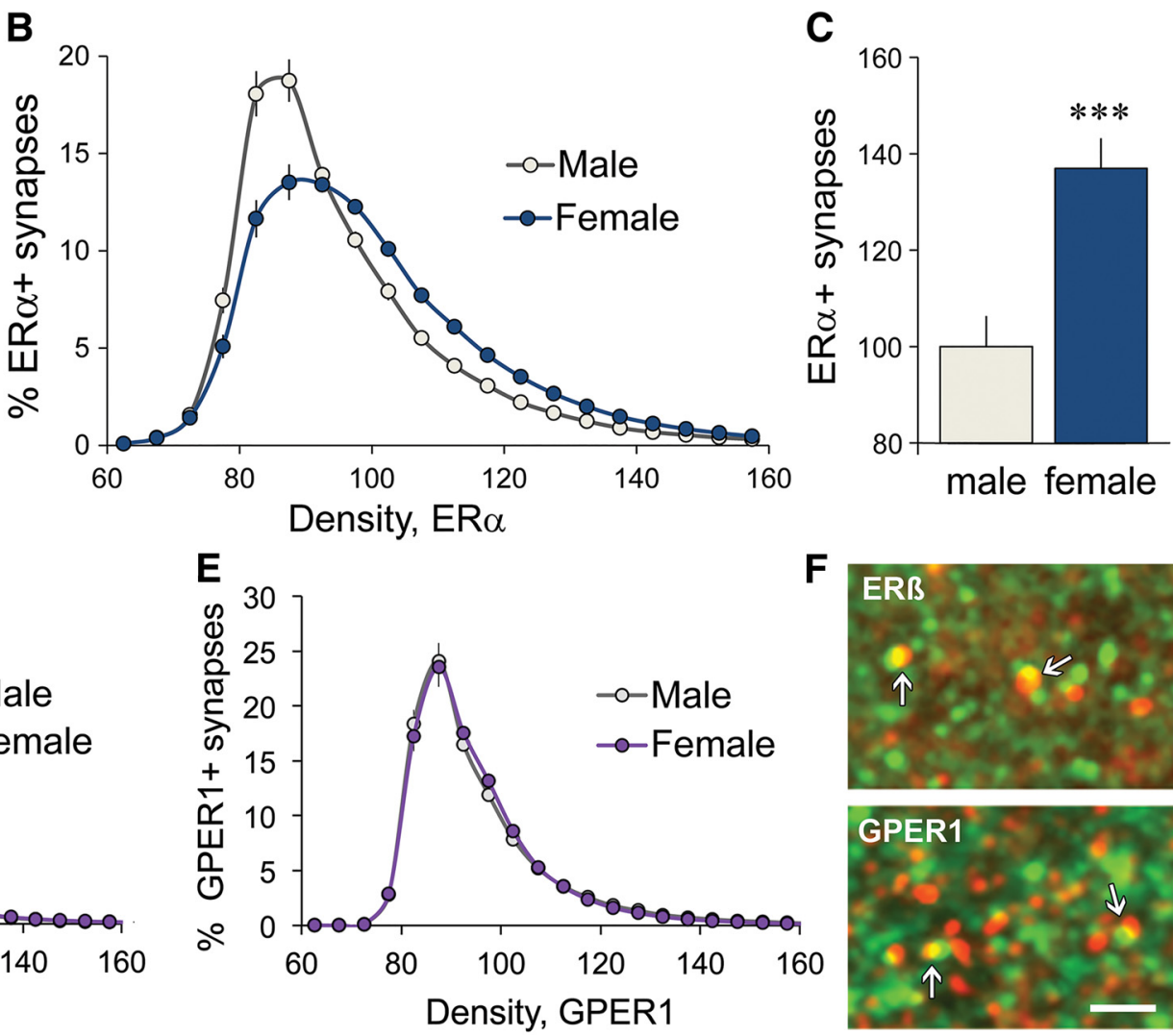

Figure 5. ER $\alpha$ is present at higher concentrations in female than in male CA1 synapses. $\boldsymbol{A}$, Top left, Deconvolved two-photon microscopic images of immunofluorescent labeling were used to construct a 3D montage of the (A1 sample field (shown); one can see that a subpopulation of PSD-95-IR contacts (green) also contains ER $\alpha$ immunoreactivity (double labeling appears yellow). Scale bar, $2 \mu \mathrm{m}$. Top right, Image of a single double-labeled PSD shows the spatial relationship of areas occupied by PSD-95 (green) and ER $\alpha$ (red) immunoreactivities and the extent of overlap (merge, yellow). Scale bar, $0.1 \mu \mathrm{m}$. Bottom, Image shows the montage from the same $z$-stack illustrated in the top left but with the top of that panel rotated away from the viewer to show double labeling of the same puncta (arrows) from a different 3D viewpoint. $\boldsymbol{B}$, The density frequency distribution for ER $\alpha$-IR (colocalized with PSD-95) shows a greater rightward skew in females relative to males $\left(p<0.0001, F_{(19,646)}=17.28\right.$; males, $n=12$; female, $\left.n=24\right)$. C, Bar graph shows the percentage of double-labeled synapses with high concentrations of ER $\alpha$ immunolabeling (density units of $\geq 90)$ normalized to the mean male value shows that there were far more dense ER $\alpha$-IR synapses in females than in males ( $\left.{ }^{* * *} p=0.0001, t_{(34)}=4.40\right)$. $\boldsymbol{D}, \boldsymbol{E}$, Density frequency distributions for all synapse-sized clusters of ER $\beta(\boldsymbol{D})$ and GPER1 (E) immunoreactivities colocalized with PSD-95 in the CA1 SR sample field ( $n=12 / \mathrm{group}$, females in diestrus). For ER $\beta$-IR ( $\boldsymbol{D}$ ), there was a significant interaction between sex and immunolabeling density $\left(p=0.0005, F_{(21,462)}=2.4\right)$ because of a slightly greater proportion of synapses with low-density ER $\beta$-IR (density units $83-88$ ) in males than in females. There was no effect of sex on the numbers of densely ER $\beta$-IR synapses (density units, $\left.\geq 90 ; p=0.12 ; t_{(22)}=1.6\right)$. For GPER1-IR, there were no group differences (GPER1: $p=0.89$; $\left.F_{(20,440)}=0.33\right) . F$, Deconvolved epifluorescence images shows that ER $\beta$ and GPER1 (red) are both localized to synapse-sized puncta in CA1 SR and that some of those are colocalized with PSD-95 (green; doubles appear yellow). Scale bar, $2 \mu \mathrm{m}$.

mechanisms in females but not in males. We used dual immunofluorescence for PSD-95 and ER $\alpha$ (Fig. 5A), and quantitative FDT to determine whether this sex difference reflects differences in the abundance of synaptic ER $\alpha$. First, there was no effect of sex on the numbers of PSD-95-IR contacts $\left(p=0.12, t_{(22)}=1.603 ; 6\right.$ male, 12 female slices). The immunolabeling density frequency distribution for synaptic (PSD-95 colocalized) ER $\alpha$ had a far greater rightward skew for females than for males (Fig. 5B), resulting in a significantly higher proportion of synapses with dense $\mathrm{ER} \alpha$-IR (i.e., contacts with immunofluorescent density of $\geq 90$; Fig. $5 C$ ). This held for females that were or were not in proestrus, as determined by histological assessment of vaginal smears. To determine whether there are similar effects of sex on $\operatorname{ER} \beta$ and GPER1 immunoreactivities, additional rats were processed for FDT to quantify synaptic immunolabeling in CA1 SR. Both ER $\beta$ and GPER1 were predominantly localized to synapse-sized puncta scattered across the sample field, many of which were clearly colocalized with PSD-95 (Fig. 5F). The immunolabeling density frequency distributions for synaptic (PSD-95 colocalized) ER $\beta$ were slightly different between males and females because of a somewhat greater proportion of synapses with low- density (83-88 units) ER $\beta$-IR in males (Fig. $5 D$ ). The density frequency distributions for GPER1-IR were not significantly different between sexes (Fig. $5 E$ ). In contrast to $\mathrm{ER} \alpha$, there were no significant male-female differences in the proportion of PSDs with dense ( $\geq 90$ density units) immunolabeling for $\operatorname{ER} \beta$ ( $p=$ $\left.0.12, t_{(22)}=1.6\right)$ or GPER1 $\left(p=0.69, t_{(22)}=0.4\right)$. As with prior cohorts, there were no effects of sex on numbers of PSD-95-IR synapses in the CA1 SR sample field $\left(p=0.20, t_{(22)}=1.32 ; n=\right.$ 12/sex).

Sex differences in concentrations of ERs have been described previously in brain (Brown et al., 1992), and greater total numbers of extranuclear ER $\alpha$-IR elements (including dendrites, glia, spines, and boutons) have been described for field CA1 of female mice in diestrus compared with male mice (Mitterling et al., 2010), but the present results constitute novel evidence for significant sex differences at excitatory hippocampal synapses independent of female estrous cycle state. The marked dimorphism in synaptic $\mathrm{ER} \alpha$ levels described here provides a plausible explanation for at least some of the sex differences in the contributions of neurosteroid estrogen to hippocampal LTP. 


\section{Downstream LTP stabilization mechanisms are comparable between the sexes \\ $\beta 1$-integrins}

We tested if sex differences extend to elements known to regulate the cytoskeletal reorganization that consolidates LTP in males (Rex et al., 2009; Babayan et al., 2012; Lynch et al., 2013; Rudy, 2015) beginning with an analysis of TBS effects on synaptic $\beta 1$ integrins. In male field CA1, TBS activates postsynaptic integrins containing the $\beta 1$ subunit and integrin-dependent signaling to actin, a sequence that is required for stable LTP (Kramár et al., 2006; Babayan et al., 2012; Wang et al., 2016a). Antisera that are specific for the activated (Act) form of $\beta 1$ integrin label discrete puncta in field CA1 SR, a subset of which are colocalized with PSD-95 (Fig. 6A). Using FDT to evaluate the effects of S-C stimulation on levels of integrin activation showed that TBS increases synaptic levels of Act- $\beta 1$ immunoreactivity in female slices as assessed 3-4 min later (Fig. 6B, C). The magnitude of this effect was comparable to that reported previously and confirmed here for males $\left(p<0.0001, F_{(21,588)}=6.80\right.$ for the intensity frequency distribution; and $p=0.046, t_{(28)}=2.08$ for the proportion of synapses with dense Act- $\beta 1$-IR, respectively; LFS vs TBS, $n=15$ slices/group).

Integrin signaling to actin is mediated in part by focal adhesion kinase (FAK), a synaptic tyrosine kinase that is robustly activated by TBS in male field CA1 (Babayan et al., 2012). Using FDT to evaluate stimulation effects on synaptic pFAK Y397-IR (Fig. 6D), we found that S-C TBS induced a comparable increase in females, but in this case the ER $\alpha$ antagonist MPP blocked TBS effects on both the greater rightward skew in the pFAK immunolabeling density frequency distribution and the proportion of PSDs with dense pFAK immunoreactivity (Fig. 6E,F). We then tested whether in females, as in males, $\beta 1$ integrin engagement is required for LTP in experiments using slices from cKO mice in which the expression of $\beta 1$ integrin by excitatory forebrain neurons is reduced beginning at $\sim 3$ weeks of age (Chan et al., 2006; Huang et al., 2006; Wang et al., 2016a). For female $\beta 1$ integrin cKOs, as previously determined for males (Wang et al., 2016a), the S-C I/O curves and baseline synaptic responses were not detectably different from those of WTs (Fig. 6G). Nevertheless, LTP stabilization was severely impaired in the cKOs (Fig. $6 H$ ). $\beta 1$ family integrins fall into two groups, which are distinguished by whether or not they bind matrix ligands containing the amino acid sequence arg-gly-asp (RGD; Humphries et al., 2006). We found that the potent disintegrin echistatin, a toxin that inhibits RGD-binding integrins, disrupted LTP stabilization in females (Fig. 6I), as was previously shown for males (Kramár et al., 2006).

\section{BDNF signaling}

The neurotrophin BDNF, acting on synaptic TrkB receptors, is critical for TBS-induced dendritic spine actin polymerization and the production of stable LTP in male hippocampus (Figurov et al., 1996; Kramár et al., 2004; Rex et al., 2007; Minichiello, 2009). Using dual immunolabeling for PSD-95 and pTrkB Y515 (Fig. 7A) in combination with FDT, we determined that TBSinduced increases in synaptic pTrkB are $\mathrm{ER} \alpha$ dependent (i.e., fully blocked by MPP) in females, as is evident in both immunolabeling density frequency distributions and analyses of the proportions of PSDs containing particularly dense pTrkB immunoreactivity (Fig. $7 A$ ). In contrast, in males the similarly robust TBS-induced increases in postsynaptic pTrkB immunoreactivity were unaffected by ER $\alpha$ antagonism (Fig. $7 B$ ). We then confirmed that TrkB is critical for LTP in females, as in males, using the TrkB inhibitor ANA-12 (Zhang et al., 2015; Fig. 7C). Previous work showed that, in male field CA1, TrkB activation by infused E2 is dependent upon $\beta 1$ integrin function (Wang et al., 2016a), a finding consistent with reports that integrins enable the activities of neighboring transmembrane receptors in many circumstances (Meng et al., 2011; Munger and Sheppard, 2011). We tested for similar receptor cross talk in the instance of female LTP by evaluating TBS effects on TrkB in the presence and absence of functioning $\beta 1$ integrins: the increase in synaptic pTrkB levels produced by a single TBS train in slices from female WT mice was not present in age-matched female $\beta 1 \mathrm{cKOs}$ (Fig. $7 D$ ), thereby showing that in females synaptic TrkB activation was $\beta 1$ integrin dependent.

\section{Actin signaling}

Both $\beta 1$ integrin and TrkB engage actin regulatory signaling involving the small GTPase RhoA and its effectors ROCK, LIM kinase, and cofilin. These events are critical for the production of stable S-C LTP in males (Rex et al., 2009; Lynch and Gall, 2013). Similar signaling was identified in females. Using dual immunolabeling and FDT, we determined that in females TBS increased levels of phosphorylated cofilin (Ser3)-IR colocalized with PSD-95 (Fig. 7E), as described for males (Chen et al., 2007), and that the infusion of the ROCK inhibitor H1152 eliminated TBS-induced S-C potentiation (Fig. $7 F$ ).

In all, we found no evidence for sex differences in the complex, downstream signaling events required for LTP consolidation other than the dependency on ER $\alpha$ in females.

\section{Sexual dimorphism in LTP and learning threshold}

TBS, which mimics cell firing during learning (Otto et al., 1991), is near optimal for inducing LTP in males (Larson et al., 1986) and generates a similar degree of potentiation in females (Kramár et al., 2009). In accord with previous work (Bi et al., 2001), the percentage of LTP induced by a 10-burst TBS train was slightly higher in slices collected from females in proestrus (high circulating estrogen levels) than from females not in proestrus (52.0 \pm $4.1 \%$ vs $37.9 \pm 4.5 \%$, respectively; $p=0.047$; proestrus, $n=7$; non-proestrus, $n=5$ ). Nevertheless, we observed substantial sex differences in LTP threshold: five pairs of theta bursts, delivered at 2 min intervals, produced significant S-C LTP in slices from male rats, as described previously (Larson et al., 1993), but not in those from female rats (Fig. 8A). Differences were evident after the first three burst pairs; male responses continued to increase with subsequent bursts, whereas female responses did not (Fig. $8 B)$. We next tested whether the threshold for LTP corresponds to that for activating synaptic ERK1/2: the minimum condition for inducing potentiation was sufficient to cause a robust increase in synaptic pERK1/2-IR in males but not in females (Fig. 8C). In contrast to the effects of paired theta bursts, we found that four sets of three bursts, separated by $2 \mathrm{~min}$, generated robust LTP in females (Fig. $8 D$ ) with individual fEPSPs progressively increasing in size after each triplet (Fig. $8 E$ ). These results constitute the first evidence that adult females have a higher threshold for S-C potentiation than do males.

Bath infusion of $1 \mathrm{nM}$ E2 lowered the LTP threshold (to paired bursts) in females to the level found in untreated males. As predicted from the above kinase studies, antagonists to either ER $\alpha$ or $\mathrm{ER} \beta$ significantly attenuated the enhancing effects of E2 infusion on female LTP (Fig. 8F).

The LTP threshold results predict that females will require measurably more training than males to encode memories that are dependent on plasticity in field CA1. We tested this using object location (i.e., object placement) memory [object location 

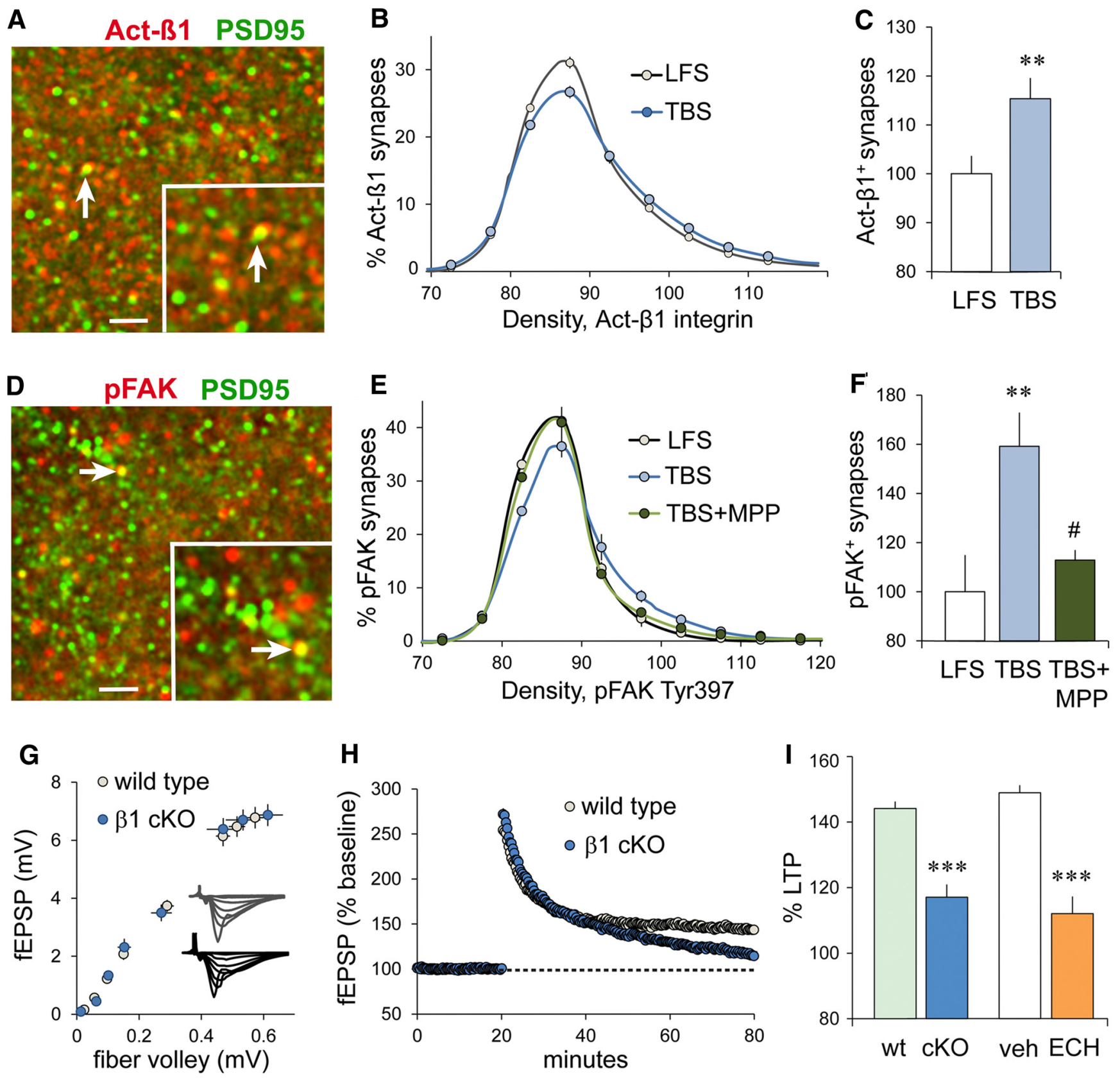

Figure 6. Female S-CLTP depends on an RGD-binding $\beta 1$ integrin. $A$, Image shows dual immunolabeling for Act- $\beta 1$ integrin (red) and PSD-95 (green) in CA1 SR; inset shows the area surrounding a double-labeled PSD (arrow) at higher magnification. Scale bars: $A, D$, large image, $10 \mu \mathrm{m} ; A, D$, inset, $2 \mu \mathrm{m}$. $\boldsymbol{B}$, Plot shows the immunolabeling density frequency distributions for Act- $\beta 1$-IR colocalized with PSD-95 in CA1 SR in female slices that received LFS or TBS of S-C projections; with TBS, compared with LFS, there was a greater rightward skew in the Act- $\beta 1$ density frequency distribution, indicating an increase in the proportion of synapses with dense Act- $\beta 1-\operatorname{IR~}\left(p<0.0001 ; F_{(21,882)}=7.91 ; n=22 /\right.$ group $)$. C, The percentage of double-labeled PSDs with dense Act- $\beta 1-\operatorname{IR}(>90$ units on $\boldsymbol{B})$, normalized to the mean of the LFS control group, showed that TBS increased the numbers of Act- $\beta 1$-enriched synapses $\left({ }^{* *} p=0.009, t_{(42)}=2.75\right)$. $\boldsymbol{D}$, Deconvolved image shows colocalization of pFAK (red) and PSD-95 (green) immunoreactivities; double labeling appears yellow (arrows); inset shows the area surrounding a double-labeled PSD (arrow) at higher magnification. $E$, TBS increased the rightward skew in the density frequency distribution for synaptic (PSD-95 colocalized) pFAK-IR $\left(p<0.0001, F_{(19,323)}=6.294\right)$ that was largely eliminated by ER $\alpha$ antagonist MPP $\left(p<0.0001, F_{(19,285)}=7.514 ; \mathrm{LFS}, n=10 ; \mathrm{TBS}, n=9 ; \mathrm{TBS}+\mathrm{MPP}, n=8\right) . \boldsymbol{F}$, The percentage of double-labeled synapses with high concentrations of $p F A K(>90$ units), normalized to LFS control slices, was increased by TBS; MPP blocked this pFAK increase $\left(p=0.0037, F_{(2.26)}=7.13\right.$; Bonferroni's post-test: LFS vs TBS, ${ }^{* *} p<0.01 ;$ TBS vs TBS + MPP, \#p $\left.<0.05\right)$. $\boldsymbol{G}$, The fiber volley amplitude vs fEPSP amplitude relationship (I/O curve) for female wild-type and $c K 0$ mice were comparable $\left(p=1.0, F_{(7,126)}=0.01 ; n=9 /\right.$ group). $\boldsymbol{H}$, Plot of fEPSP slopes (expressed as a percentage of the mean baseline response) shows that in female mice TBS (applied at $20 \mathrm{~min}$ ) induced robust LTP in wild types, whereas, in $\beta 1 \mathrm{cKOs}$, potentiation declined toward baseline over $60 \mathrm{~min}$. $I$, The percentage of LTP (expressed as the percentage at baseline) measured at $55-60 \mathrm{~min}$ post-TBS was greatly reduced in female $\beta 1 \mathrm{cKO}$ mice relative to WT mice. A similarly pronounced suppression of female LTP was produced by the RGD-binding $\beta 1$ integrin blocker echistatin (ECH) infused for 40 min before $\operatorname{TBS}\left(p<0.0001, F_{(3,27)}=24.01 ;\right.$ post hoc tests: WT vs cKO and veh vs $\mathrm{ECH},{ }^{* * *} p<0.001 ; n=9 /$ group).

memory (OLM); Fig. 8G], which depends on synaptic plasticity in CA1 (Barrett et al., 2011; Babayan et al., 2012) and is facilitated by E2 action in hippocampus (Inagaki et al., 2010; Boulware et al., 2013). OLM in males requires 5 min of training, is associated with elevated synaptic pERK1/2, and requires $\beta 1$ integrin function (Babayan et al., 2012; Seese et al., 2014). Tests in females showed that one $5 \mathrm{~min}$ training trial supports long-term OLM for mice in proestrus (Fig. $8 \mathrm{H}$ ) but not for those outside proestrus, although 


\section{A}
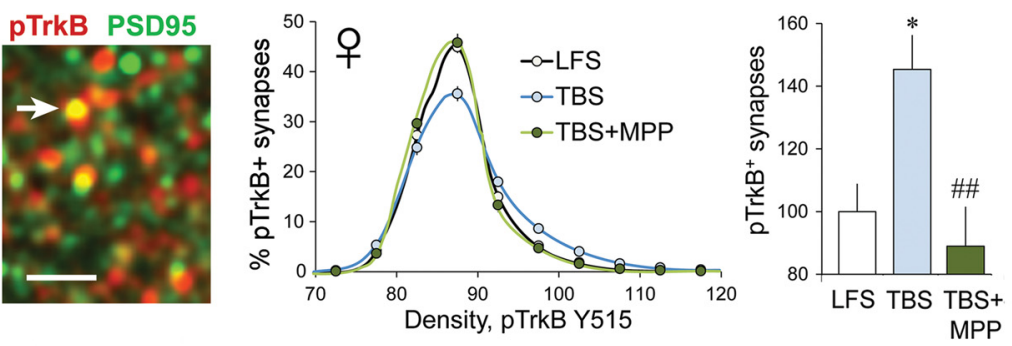

B
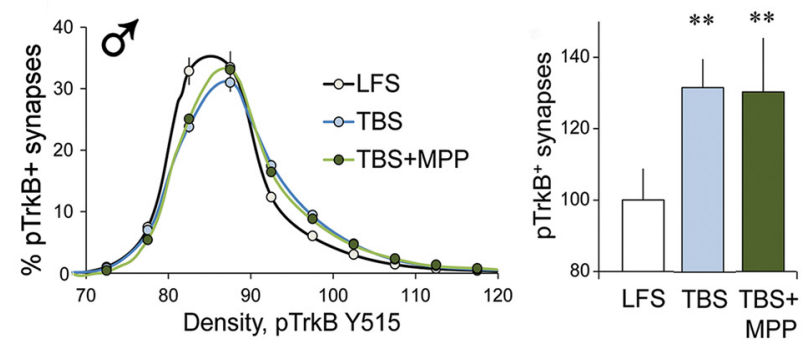

C

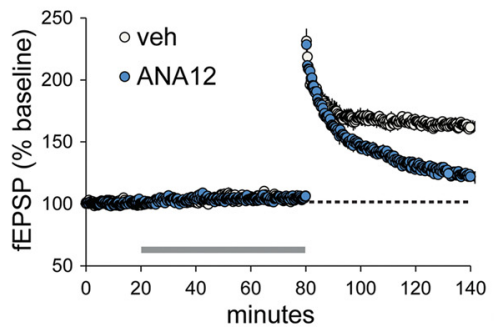

E
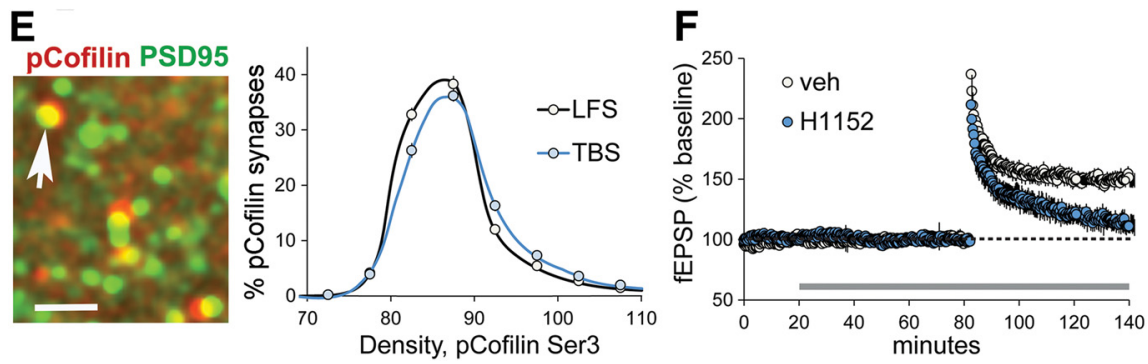

Figure 7. Synaptic TrkB activation depends on ER $\alpha$ and $\beta 1$ integrin, and is required for LTP in females. $A$, Deconvolved image shows punctate localization of pTrkB Y515 (red) and PSD-95 (green); yellow indicates double labeling (arrow). Scale bar, $2 \mu \mathrm{m}$. Line graph shows that TBS, compared with LFS, caused a greater rightward skew in the density frequency distribution for pTrkB-IR colocalized with PSD-95 $\left(p<0.0001, F_{(19,342)}=10.44\right)$, and MPP substantially reduced this effect $\left(p<0.0001, F_{(19,342)}=\right.$ $10.66 ; n=10$ /group). Right, The percentage of double-labeled synapses with dense $\operatorname{PTkB}-\operatorname{IR}$ ( $\geq 90$ units) was elevated after TBS in vehicle-treated, but not in MPP-treated, female slices (group means normalized to the LFS group mean; $p=0.0025, F_{(2,29)}=$ 7.55; post hoc tests: LFS vs TBS, ${ }^{*} p<0.05$; TBS vs TBS + MPP, \#\#p < 0.01). $B$, In slices from male rats, TBS increased both (left) the rightward skew in the synaptic PTrkB-IR density frequency distribution (vs LFS, $p<0.0001 ; F_{(19,342)}=6.794$ ) that was not influenced by MPP ( $p=0.939 ; F_{(19,342)}=0.549, n=10 /$ group) and (right) the percentage of PSD-95-IR synapses associated with dense $\operatorname{PTrkB}-\mathrm{IR}$ ( $\geq 90$ units), also not influenced by $\operatorname{MPP}\left(p=0.009, F_{(2,29)}=5.68\right.$; Bonferroni's post-test: ${ }^{* *} p<0.01$ vs LFS). C, TrkB blocker ANA-12 (750 nm) disrupted the stabilization of CA1 LTP in female slices $\left(p<0.0001, t_{(10)}=8.36 ; n=\right.$ 6/group). D, S-C TBS produced a marked increase in the percentage of PSDs associated with dense PTrkB-IR in wild-type mice but not in $\beta 1$ integrin cKOs $\left(p<0.0001, F_{(3,36)}=25.55\right.$; posthoctests: LFS vs TBS for wild types, ${ }^{* * *} p<0.0001 ; \mathrm{LFS}, n=9 ;$ TBS, $n=$ 8; LFS vs TBS for $\beta 1$ cK0s, n.S.; $n=10$ /group). $E$, Image shows pCofilin-IR colocalized with PSD-95 in female CA1 SR. Right, In females, S-C TBS increased the rightward skew in the density frequency distribution for synaptic $p$ Cofilin (relative to LFS; $p<$ $0.0001, F_{(19,399)}=7.69 ;$ LFS, $n=12 ;$ TBS, $\left.n=11\right) . F$, The selective ROCK inhibitor H1152 (100 nm, 160 min) blocked S-C LTP in female slices $\left(p=0.0013, t_{(9)}=4.57 ;\right.$ veh, $\left.n=6 ; H 1152, n=5\right)$.

the total time spent exploring cues did not differ across cycle stages during training or testing (training: $p=0.95, t_{(18)}=0.06$; testing: $p=0.57, t_{(18)}=0.58$; two-tailed $t$ test; proestrus, $n=8$; non-proestrus, $n=12$ ). Peripheral injections of either ER $\alpha$ antagonist MPP or ER $\beta$ antagonist PHTPP blocked long-term OLM (assessed $24 \mathrm{~h}$ after training; Fig. $8 I$ ) by females in proestrus, also without an effect on exploratory behavior (training: $p=$ $0.99, F_{(2,17)}=0.003$; testing: $p=0.97, F_{(2,17)}=0.032$; veh, $n=6$;
MPP, $n=5$; PHTPP, $n=7$; one-way ANOVA). Neither inhibitor affected OLM by males $\left(p=0.99 ; F_{(2,3)}=0.64\right.$; veh, $n=7$; MPP and PHTPP, $n=6$ each; one-way ANOVA).

Finally, we asked whether learning object location depends upon ER $\alpha$-dependent engagement of signaling through kinases associated with LTP. Females in proestrus were given a $5 \mathrm{~min}$ OLM training trial and then immediately killed for pERK1/2 immunofluorescence. FDT analyses of synaptic immunolabeling of the CA1 dendritic lamina evaluated in LTP studies (Fig. $8 \mathrm{~J}$ ) identified an elevated proportion of PSDs associated with dense pERK1/ 2-IR relative to similarly staged control female mice. The $\mathrm{ER} \alpha$ antagonist MPP blocked training-induced increases in synaptic pERK1/2 (Fig. $8 K$ ). Finally, 5 min of OLM training did not increase synaptic pERK-IR in non-proestrus females (Fig. $8 L$ ), a result that accords with the absence of learning in these mice.

\section{Discussion}

Sexual dimorphisms in brain and their contributions to male/female differences in learning are topics of broad and increasing interest (Scharfman and MacLusky, 2008; Andreano and Cahill, 2009; Luine, 2014; Choleris et al., 2018). The present results point to striking yet unexpectedly discrete sex differences in functional plasticity of excitatory synapses, within a hippocampal field critical for memory formation, that are likely to be centrally involved in the encoding of spatial information.

We previously showed that the well described facilitation of synaptic responses produced by exogenous E2 in adult male CA1 (Woolley, 2007) is due to partial and reversible activation of postsynaptic actin-regulatory signaling that is required for LTP consolidation (Kramár et al., 2009). Infused E2 also markedly lowered the threshold and increased the magnitude of LTP in males. Using selective agonists, we determined that these effects of applied $\mathrm{E} 2$ were initiated by $\mathrm{ER} \beta$, with no evident contribution from $\mathrm{ER} \alpha$ or GPER1 (Kramár et al., 2009; Wang et al., 2016a). The most upstream $\operatorname{ER} \beta$-initiated events identified in those experiments included activation of synaptic $\beta 1$ integrins and integrin-dependent transactivation of TrkB (Wang et al., 2016a); these two receptors are critical for LTP-related actin remodeling in dendritic spines (Kramár et al., 2006; Rex et al., 2007; Bramham, 2008; Wang et al., 2008). Here we identified still earlier events set in motion by E2 application in CA1 of females only: $\mathrm{ER} \alpha$ contributes to the engagement of NMDAR-associated kinases ERK1/2 and Src, which in turn regulate $\beta 1$ integrin and 

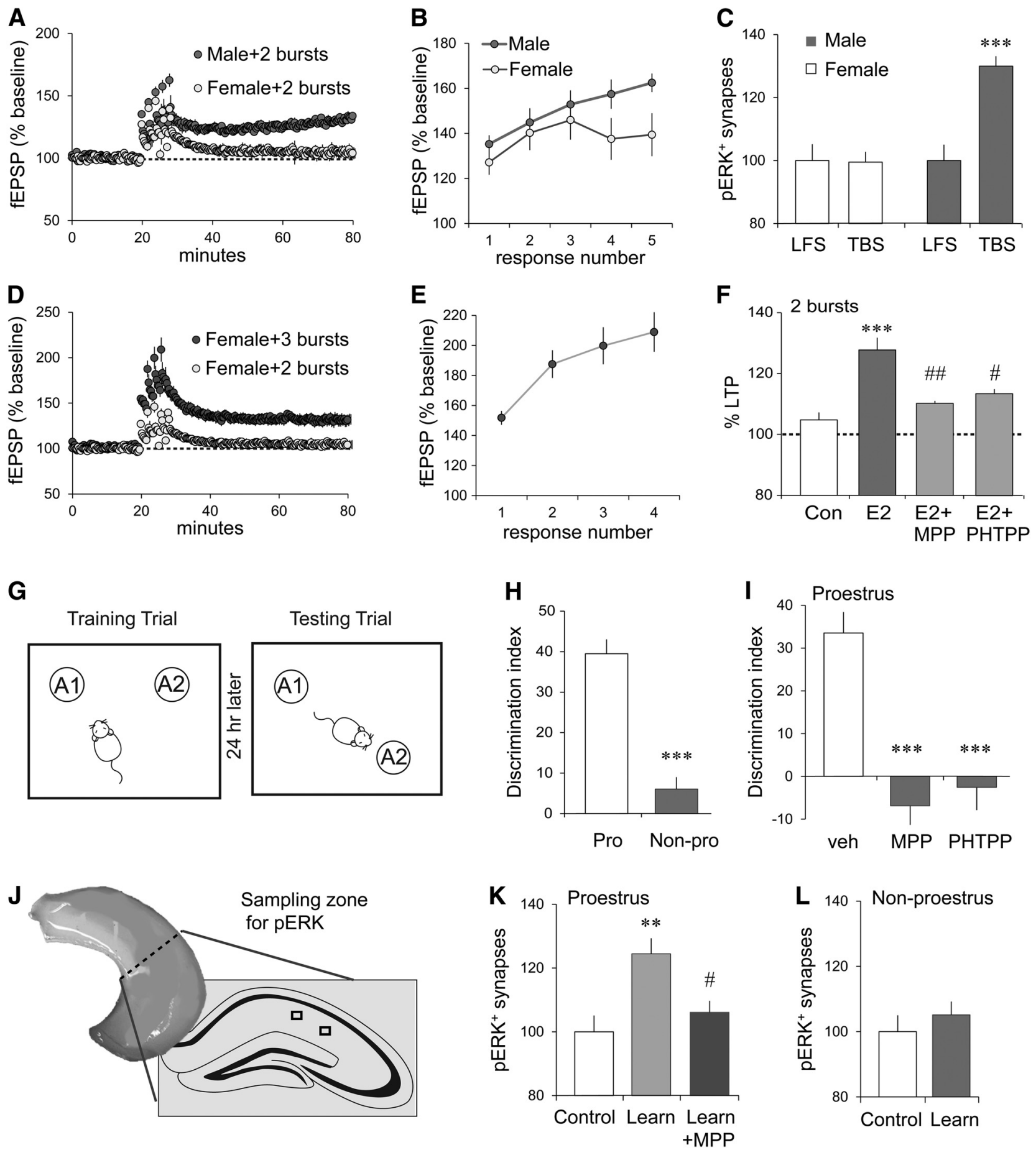

Figure 8. Sex differences in thresholds for LTP and spatial learning. A, Five pairs of two theta bursts produced significant S-CLTP in male but not in female CA1 ( $p=0.0005, t_{(11)}=4.86$; female, $n=7$; male, $n=6) \cdot \boldsymbol{B}$, The S-C fEPSP slope immediately after each burst pair increased steadily across the first three pairs for both sexes but diverged for the last two pairs $\left(p=0.045, F_{(4,44)}=\right.$ 2.666). C, Five pairs of two theta bursts increased the percentage of CA1 SR synapses with dense pERK1/2-IR in male but not female slices (values normalized to the mean of their respective LFS groups; one-way ANOVA: $p<0.0001, F_{(3.56)}=11.28$; post hoc tests: male TBS vs each other group, ${ }^{* * *} p \leq 0.0001 ; 14-16$ slices/group). D, Four sets of TBS triplets (three bursts, 200 ms between bursts, 2 min between triplets) produced significant LTP in female slices $\left(p=0.0025, t_{(11)}=3.91 \mathrm{vs} 2\right.$ in burst group; $n=6 /$ group). $E$, The fEPSP slope immediately after each burst triplet steadily increased ( 150\% to 209\% of baseline). $\boldsymbol{F}$, E2 (1 nM), perfused for 10 min before collecting baseline responses and continued 30 min more, increased LTP magnitude in females (five pairs of theta bursts, LTP expressed as the percentage of baseline); this enhancement was significantly attenuated by either ER $\alpha$ antagonist MPP or ER $\beta$ antagonist PHTPP applied 30 min before and during E2 application $\left(p=0.0001, F_{(3,25)}=9.52\right.$, one-way ANOVA; post hoc tests: con vs E2, ${ }^{* * *} p=0.0001 ; \mathrm{E2}$ vs E2 + MPP, \#\#p =0.003; E2 vs E2 + PHTPP, \#p < 0.02; con vs E2 + MPP or E2 + PHTPP, $p>0.35$ ). G, For 0LM training, mice explored the chamber containing two identical objects (A1 and A2); for testing $24 \mathrm{~h}$ later, they returned to the chamber with one of the objects moved to a novel location. $\boldsymbol{H}$, With 5 min of training, OLM was greater for proestrus (Pro) than non-proestrus (Non-pro) mice (signified by DI; *** $p<0.0001, t_{(18)}=7.27 ;$ Pro, $n=8 ;$ Non-pro, $n=12$ ). I, MPP or PHTPP $(0.6 \mathrm{mg} / \mathrm{kg})$ blocked OLM in proestrus mice $\left(p<0.0001, F_{(2,17)}=28.94 ;\right.$ post hoc tests: veh vs MPP, ${ }^{* * *} p<0.001 ;$ veh vs PHTPP, ${ }^{* * *} p<0.001 ;$ veh, $n=6 ;$ MPP, $n=5 ;$ PHTPP, $\left.n=7\right)$. $J$, Location of CA1 fields for measures of pERK-IR. $\boldsymbol{K}$, After $5 \mathrm{~min}$ of $0 \mathrm{LM}$ training in proestrus, the numbers of dense pERK1/2-IRPSDs were increased in mice that sampled the objects relative to those that explored an empty chamber; this effect was blocked by $\operatorname{MPP}\left(p=0.003, F_{(2.23)}=7.78\right.$; Control vs Learn, ${ }^{* *} p<0.01$; Learn vs Learn + MPP, \#p $<0.05 ; n=8 /$ group; normalized to control mean). $L$, The 5 min of $0 L M$ training did not affect the numbers of dense pERK1/2-IR PSDs in non-proestrus mice ( $p=0.44, t_{(23)}=0.79$; Control, $n=13$; Learn, $n=12$ ). 
A
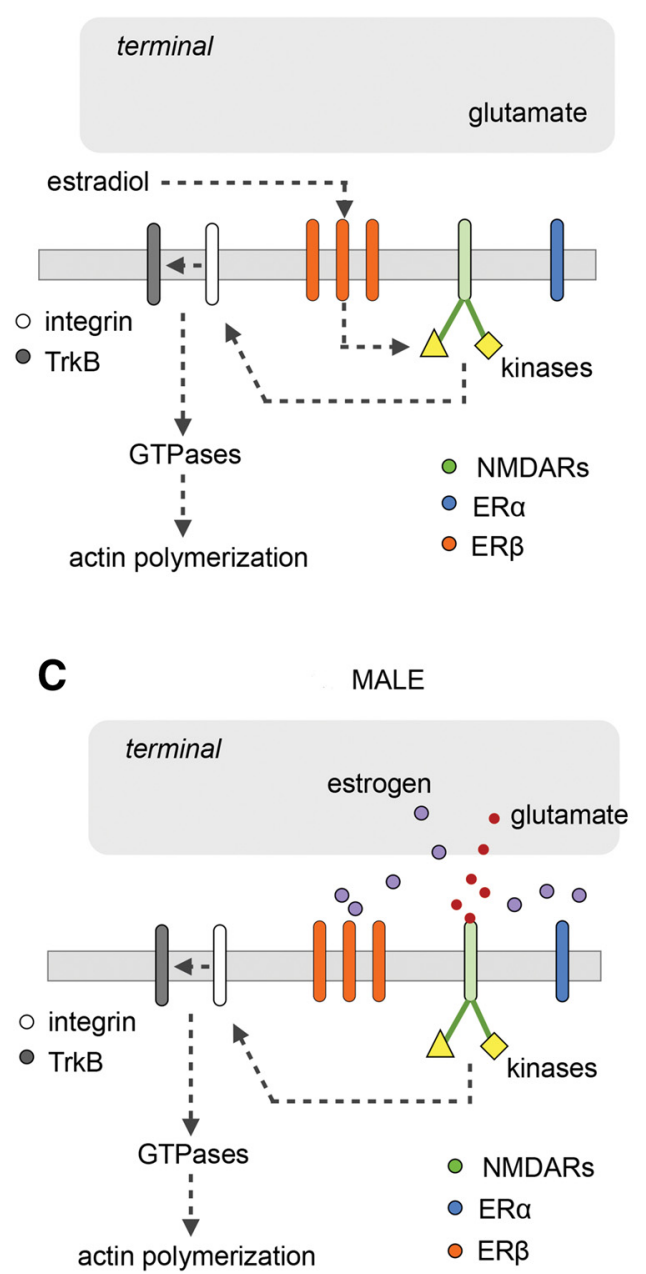

B

FEMALE

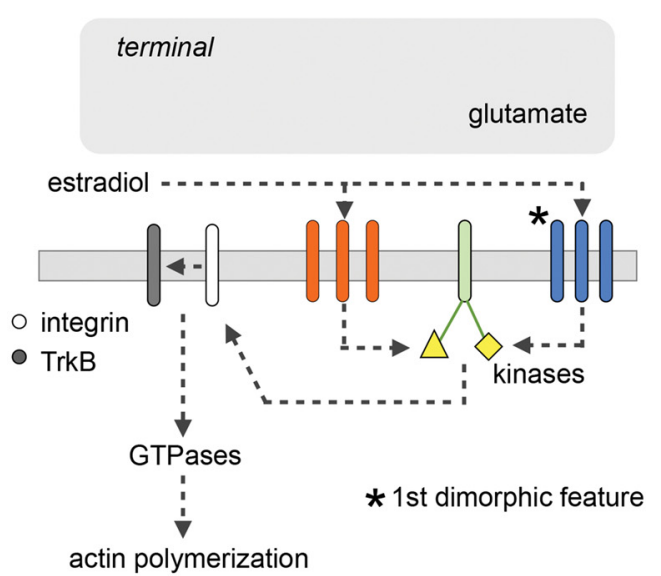

D

FEMALE

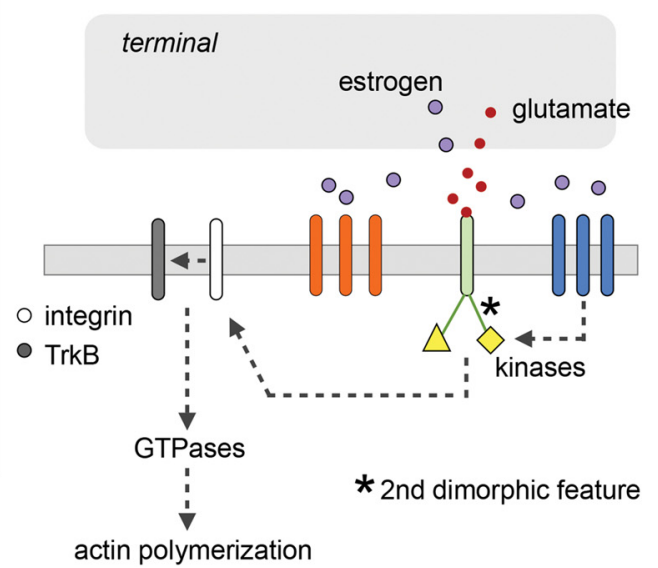

Figure 9. A two-factor hypothesis for sexual dimorphism at hippocampal synapses. A, Prior studies showed that, in male hippocampus, infused E2 acts via ER $\beta$ to stimulate modulatory receptors ( $\beta 1$ integrins, TrkB) leading to actin signaling and transiently enhanced baseline synaptic responses. Experiments described here demonstrate that E2 engages two NMDAR-associated kinases (ERK1/2, Src) that are upstream from these events; in males, this effect is mediated by ER $\beta$ with no detectable contribution from ER $\alpha$. $\boldsymbol{B}, \mathrm{E} 2$ application also activates the two kinases in females, but the response to exogenous $E 2$ is mediated by both $E R \alpha$ and $E R \beta$. It is proposed that this sex difference reflects the greater concentration of ER $\alpha$ in female synapses (first dimorphic feature). $C$, Induction of LTP in males activates the two NMDAR-related kinases and downstream signaling events that stabilize the potentiated state. These downstream steps, and LTP itself, do not depend on local estrogen, $E R \alpha$, or ER $\beta$. D, LTP induction in females also activates ERK1/2 and Src but, in contrast to males, the effect is dependent upon ER $\alpha$. We propose that the functional links between NMDARs and the kinases are weaker in females than in males (second dimorphic feature), and so kinase activation requires a boost from released estrogen and stimulation of ER $\alpha$. The dependency upon local estrogen is accompanied by a higher threshold for LTP in females, an effect that can be offset by exogenous estradiol acting via mechanisms described in $\boldsymbol{B}$.

TrkB function (Fincham et al., 2000; Chen et al., 2010). Results further show that in females E2 infusion lowers the threshold for LTP but- unlike the case for males- both $\operatorname{ER} \alpha$ and $\operatorname{ER} \beta$ contribute to this effect. We conclude that exogenous E2 mobilizes ER $\beta$ signaling at excitatory S-C synapses in both sexes but triggers significant contributions from $\mathrm{ER} \alpha$ in females only. Quantitative immunofluorescence uncovered one factor likely contributing to this synaptic dimorphism: in CA1, the proportion of excitatory synapses containing high concentrations of $\mathrm{ER} \alpha$ was substantially greater in females than in males, whereas the numbers of synapses enriched in ER $\beta$ or GPER1 did not differ between the sexes. Figure 9, $A$ and $B$, summarizes these findings.

Sex differences in the abundance of synaptic $\mathrm{ER} \alpha$ are somewhat surprising given comparable levels of $\operatorname{ER} \alpha$ and $\operatorname{ER} \beta$ gene expression (Meitzen et al., 2017) and numbers of expressing neurons (Weiland et al., 1997; Zuloaga et al., 2014) in adult hippocampus. These findings suggest there may be dimorphisms in
$\mathrm{ER} \alpha$ trafficking. Male/female differences in the expression of proteins that enable $\mathrm{ER} \alpha$ membrane delivery and signaling have been reported (Meitzen et al., 2017), but the levels of these proteins near the synapse are not known. Related to compartmentalization, it should be noted that the FDT technique used here allows for measures of ER $\alpha$ colocalized with PSD-95, and thus positioned near the synapse in the postsynaptic compartment, but does not describe ER $\alpha$ levels deeper within the spine or in membrane-bound versus cytosolic pools. In evaluating synaptic localization of the glucocorticoid receptor (GR), we found good agreement between FDT (GR colocalization with PSD-95) and counts of GR-IR aggregates within spine heads of GFP-expressing neurons but also observed GR aggregates within spine necks that would not have been quantified by FDT (Jafari et al., 2012). It will be interesting to determine whether sex differences in ER $\alpha$ levels extend away from the synapse to influence suggested parasynaptic functions such as translation control (Milner et al., 2001; Mitterling et al., 2010). 
The activation of synaptic Src, ERK1/2, and TrkB is a critical early step in the production of LTP, as has been extensively characterized in male field CA1 (Figurov et al., 1996; Sweatt, 2001; MacDonald et al., 2006; Chen et al., 2010; Seese et al., 2012). The present experiments using selective ER antagonists showed that with TBS, postsynaptic activation of each of these kinases, and induction of LTP itself, depends on ER $\alpha$ in females, but not in males. We found no evidence for contributions of ER $\beta$ to TBSinduced signaling responses or LTP in either sex. The critical involvement of ER $\alpha$ in LTP in females only was further demonstrated in studies of NOER and MOER mice that express only the nuclear or membrane variant of $\mathrm{ER} \alpha$, respectively; these studies showed that in females LTP depends upon membrane-associated $\mathrm{ER} \alpha$. Although the classical mechanism of ER action entails nuclear transport and transcriptional regulation, our results align with the growing body of evidence that signal transduction, including rapid kinase activation in neurons, can originate from the membrane receptor (Grove-Strawser et al., 2010; Roepke et al., 2011; Almey et al., 2015; Levin and Hammes, 2016; Micevych et al., 2017) and that some of this membrane signaling is sexually dimorphic (Boulware et al., 2005, 2007; Huang and Woolley, 2012).

Evidence that local estrogen effects on synaptic signaling and LTP in females depend on membrane ER $\alpha$ suggests that the absence of endogenous estrogen effects on LTP in males is due, at least in part, to lower postsynaptic $\mathrm{ER} \alpha$ levels. That said, a lack of a contribution from estrogen signaling through $\mathrm{ER} \beta$ in males is surprising. Responses to applied E2 and specific ER ligands show that both $\operatorname{ER} \alpha$ and $\operatorname{ER} \beta$ can facilitate S-C LTP (present results) and learning (Boulware et al., 2013). Thus, sex differences in the contributions of local estrogens could reflect the somewhat lower affinity of the neurosteroids for $\operatorname{ER} \beta$ relative to $\operatorname{ER} \alpha$ (Kuiper et al., 1997; Perkins et al., 2017), which may be important in the context of the presumably brief estrogen release event associated with TBS or sex differences in signaling properties of neuronal ERs and associated proteins, as considered previously (Boulware et al., 2005).

The dependence in females on $\mathrm{ER} \alpha$ for the activation of at least two NMDAR- and LTP-related kinases with TBS highlights a second aspect of synaptic dimorphism: estrogen-independent mechanisms for the activation of these kinases by patterned afferent activity must be weaker in females than in males, and this is compensated for by stronger signaling to the enzymes from local $\mathrm{ER} \alpha$ in females (Fig. 9C,D). This effect does not seem to be due to differences in NMDAR activation between the sexes. Blocking $\mathrm{ER} \alpha$ in females did not affect NMDAR-influenced physiological responses to TBS: there was no effect on initial LTP magnitude or the facilitation of burst responses across the theta train. Why then are the depolarizing potentials (absent ER $\alpha$ signaling) insufficient to activate synaptic ERK1/2 and Src or to induce LTP in females when they are clearly adequate in males? One possibility involves links between NMDARs and the kinases. With the induction of LTP, ERK1/2 activation is NMDAR dependent (Wang et al., 2007). Mechanisms of Src activation are more complex, with known contributions from NMDARs, integrins, and ephrinB receptors, among others (Salter and Kalia, 2004); nevertheless, we have found that with S-C TBS postsynaptic increases in pSrc are NMDAR dependent (Chen et al., 2010). Recent work has shown that NMDARs can activate Src via nonionic, signalosometype interactions (Weilinger et al., 2016). We propose that such nonionic relationships between the NMDARs and submembrane elements (Dore et al., 2017) may be stronger in males than in females. This idea further suggests that the relatively weaker ki- nase regulation by nonionic NMDAR function in females requires a boost from $\mathrm{ER} \alpha$ signaling to initiate downstream events necessary for LTP. Tests of this idea will be an important next step in describing the substrates for sex differences in synaptic plasticity.

The sexually dimorphic synaptic features identified here appeared to be discrete: a number of LTP-related signaling events (Lynch et al., 2013; Wang et al., 2016a) were comparable between the sexes except for the anticipated dependency on ER $\alpha$ in females. These included activity-dependent $\beta 1$ integrin and TrkB activation, integrin regulation of TrkB activation, TBS-induced increases in pCofilin, and the dependence of LTP on the actin regulatory signaling through ROCK. Thus, although the substrate map for shifting synapses into their potentiated state is still better understood for males (Lynch et al., 2013), the available data indicate that sexual dimorphisms influencing the generation of S-C LTP are limited to early stages in NMDAR-associated signaling and synaptic ER $\alpha$ levels.

The convergence of ER $\alpha$ and ER $\beta$ signaling on LTP-associated synaptic kinases suggests that the effects of circulating and local estrogen will be additive with regard to plasticity. Tests of this argument generated novel evidence that females have a higher activity threshold for the induction of LTP compared with males, and that this sex difference is eliminated by the infusion of E2 in the concentration range of circulating E2 (Mukai et al., 2010). Antagonists of either ER prevented the threshold lowering of female LTP by infused E2. These results gave rise to predictions as to the basis and pharmacology of sex differences in the acquisition of spatial memory, a process that is known to involve field CA1. Specifically, we expected that during diestrus, when circulating and hippocampal estrogens are low (Kato et al., 2013), females would have a higher threshold than males or females in proestrus for field CA1-dependent object location memory, and this proved to be the case. This finding aligns with human studies showing that encoding spatial relationships is sexually differentiated (Kimura, 1996; Andreano and Cahill, 2009).

Are there adaptive advantages associated with sex differences in the threshold for learning-related synaptic modifications? There is no a priori reason to assume that a single optimal encoding threshold applies across circumstances: certain types of signals might be effectively acquired with brief sampling and short theta burst trains while more elaborate information would be best acquired with longer trains. From this perspective, evolutionary pressures toward synaptic dimorphism would reflect male versus female probabilities for having to deal with different aspects of the environment. It will be interesting in future studies to test for sex differences in learning and associated firing patterns in the afferents of CA1, in animals exposed to complex environments that contain the semantic, spatial, and temporal elements of episodic memory, which rely on distinct components of hippocampal circuitry.

\section{References}

Almey A, Milner TA, Brake WG (2015) Estrogen receptors in the central nervous system and their implication for dopamine-dependent cognition in females. Horm Behav 74:125-138. CrossRef Medline

Andreano JM, Cahill L (2009) Sex influences on the neurobiology of learning and memory. Learn Mem 16:248-266. CrossRef Medline

Babayan AH, Kramár EA, Barrett RM, Jafari M, Häettig J, Chen LY, Rex CS, Lauterborn JC, Wood MA, Gall CM, Lynch G (2012) Integrin dynamics produce a delayed stage of long-term potentiation and memory consolidation. J Neurosci 32:12854-12861. CrossRef Medline

Barrett RM, Malvaez M, Kramar E, Matheos DP, Arrizon A, Cabrera SM, Lynch G, Greene RW, Wood MA (2011) Hippocampal focal knockout of CBP affects specific histone modifications, long-term potentiation, and 
long-term memory. Neuropsychopharmacology 36:1545-1556. CrossRef Medline

Bender RA, Zhou L, Vierk R, Brandt N, Keller A, Gee CE, Schäfer MK, Rune GM (2017) Sex-dependent regulation of aromatase-mediated synaptic plasticity in the basolateral amygdala. J Neurosci 37:1532-1545. CrossRef Medline

Bi R, Foy MR, Vouimba RM, Thompson RF, Baudry M (2001) Cyclic changes in estradiol regulate synaptic plasticity through the MAP kinase pathway. Proc Natl Acad Sci U S A 98:13391-13395. CrossRef Medline

Bock HH, Herz J (2003) Reelin activates SRC family tyrosine kinases in neurons. Curr Biol 13:18-26. CrossRef Medline

Boulware MI, Weick JP, Becklund BR, Kuo SP, Groth RD, Mermelstein PG (2005) Estradiol activates group I and II metabotropic glutamate receptor signaling, leading to opposing influences on cAMP response elementbinding protein. J Neurosci 25:5066-5078. CrossRef Medline

Boulware MI, Kordasiewicz H, Mermelstein PG (2007) Caveolin proteins are essential for distinct effects of membrane estrogen receptors in neurons. J Neurosci 27:9941-9950. CrossRef Medline

Boulware MI, Heisler JD, Frick KM (2013) The memory-enhancing effects of hippocampal estrogen receptor activation involve metabotropic glutamate receptor signaling. J Neurosci 33:15184-15194. CrossRef Medline

Bozon B, Kelly A, Josselyn SA, Silva AJ, Davis S, Laroche S (2003) MAPK, CREB and zif268 are all required for the consolidation of recognition memory. Philos Trans R Soc Lond B Biol Sci 358:805-814. CrossRef Medline

Bramham CR (2008) Local protein synthesis, actin dynamics, and LTP consolidation. Curr Opin Neurobiol 18:524-531. CrossRef Medline

Brown TJ, Naftolin F, Maclusky NJ (1992) Sex differences in estrogen receptor binding in the rat hypothalamus: effects of subsaturating pulses of estradiol. Brain Res 578:129-134. CrossRef Medline

Chan CS, Weeber EJ, Zong L, Fuchs E, Sweatt JD, Davis RL (2006) $\beta 1$ integrins are required for hippocampal AMPA receptor-dependent synaptic transmission, synaptic plasticity, and working memory. J Neurosci 26:223-232. CrossRef Medline

Chen LY, Rex CS, Casale MS, Gall CM, Lynch G (2007) Changes in synaptic morphology accompany actin signaling during LTP. J Neurosci 27:53635372. CrossRef Medline

Chen LY, Rex CS, Sanaiha Y, Lynch G, Gall CM (2010) Learning induces neurotrophin signaling at hippocampal synapses. Proc Natl Acad Sci U S A 107:7030-7035. CrossRef Medline

Choleris E, Galea LAM, Sohrabji F, Frick KM (2018) Sex differences in the brain: implications for behavioral and biomedical research. Neurosci Biobehav Rev 85:126-145. CrossRef Medline

Dore K, Stein IS, Brock JA, Castillo PE, Zito K, Sjöström PJ (2017) Unconventional NMDA receptor signaling. J Neurosci 37:10800-10807. CrossRef Medline

El Gaamouch F, Buisson A, Moustié O, Lemieux M, Labrecque S, Bontempi B, De Koninck P, Nicole O (2012) Interaction between $\alpha$ CaMKII and GluN2B controls ERK-dependent plasticity. J Neurosci 32:10767-10779. CrossRef Medline

Figurov A, Pozzo-Miller LD, Olafsson P, Wang T, Lu B (1996) Regulation of synaptic responses to high-frequency stimulation and LTP by neurotrophins in the hippocampus. Nature 381:706-709. CrossRef Medline

Fincham VJ, James M, Frame MC, Winder SJ (2000) Active ERK/MAP kinase is targeted to newly forming cell-matrix adhesions by integrin engagement and v-src. EMBO J 19:2911-2923. CrossRef Medline

$\mathrm{Fu} \mathrm{XD}$, Simoncini T (2008) Extra-nuclear signaling of estrogen receptors. IUBMB Life 60:502-510. CrossRef Medline

Giovannini MG (2006) The role of the extracellular signal-regulated kinase pathway in memory encoding. Rev Neurosci 17:619-634. Medline

Giovannini MG, Blitzer RD, Wong T, Asoma K, Tsokas P, Morrison JH, Iyengar R, Landau EM (2001) Mitogen-activated protein kinase regulates early phosphorylation and delayed expression of $\mathrm{Ca}^{2+} /$ calmodulindependent protein kinase II in long-term potentiation. J Neurosci 21: 7053-7062. CrossRef Medline

Grove-Strawser D, Boulware MI, Mermelstein PG (2010) Membrane estrogen receptors activate the metabotropic glutamate receptors mGluR5 and mGluR3 to bidirectionally regulate CREB phosphorylation in female rat striatal neurons. Neuroscience 170:1045-1055. CrossRef Medline

Hara Y, Waters EM, McEwen BS, Morrison JH (2015) Estrogen effects on cognitive and synaptic health over the lifecourse. Physiol Rev 95:785-807. CrossRef Medline
Hojo Y, Hattori TA, Enami T, Furukawa A, Suzuki K, Ishii HT, Mukai H, Morrison JH, Janssen WG, Kominami S, Harada N, Kimoto T, Kawato S (2004) Adult male rat hippocampus synthesizes estradiol from pregnenolone by cytochromes $\mathrm{P} 45017 \alpha$ and $\mathrm{P} 450$ aromatase localized in neurons. Proc Natl Acad Sci U S A 101:865-870. CrossRef Medline

Hojo Y, Higo S, Kawato S, Hatanaka Y, Ooishi Y, Murakami G, Ishii H, Komatsuzaki Y, Ogiue-Ikeda M, Mukai H, Kimoto T (2011) Hippocampal synthesis of sex steroids and corticosteroids: essential for modulation of synaptic plasticity. Front Endocrinol (Lausanne) 2:43. CrossRef Medline

Huang GZ, Woolley CS (2012) Estradiol acutely suppresses inhibition in the hippocampus through a sex-specific endocannabinoid and mGluRdependent mechanism. Neuron 74:801-808. CrossRef Medline

Huang Z, Shimazu K, Woo NH, Zang K, Müller U, Lu B, Reichardt LF (2006) Distinct roles of the $\beta 1$-class integrins at the developing and the mature hippocampal excitatory synapse. J Neurosci 26:11208-11219. CrossRef Medline

Humphries JD, Byron A, Humphries MJ (2006) Integrin ligands at a glance. J Cell Sci 119:3901-3903. CrossRef Medline

Inagaki T, Gautreaux C, Luine V (2010) Acute estrogen treatment facilitates recognition memory consolidation and alters monoamine levels in memory-related brain areas. Horm Behav 58:415-426. CrossRef Medline

Jafari M, Seese RR, Babayan AH, Gall CM, Lauterborn JC (2012) Glucocorticoid receptors are localized to dendritic spines and influence local actin signaling. Mol Neurobiol 46:304-315. CrossRef Medline

Kato A, Hojo Y, Higo S, Komatsuzaki Y, Murakami G, Yoshino H, Uebayashi M, Kawato S (2013) Female hippocampal estrogens have a significant correlation with cyclic fluctuation of hippocampal spines. Front Neural Circuits 7:149. CrossRef Medline

Kimura D (1996) Sex, sexual orientation and sex hormones influence human cognitive function. Curr Opin Neurobiol 6:259-263. CrossRef Medline

Kramár EA, Lin B, Lin CY, Arai AC, Gall CM, Lynch G (2004) A novel mechanism for the facilitation of theta-induced long-term potentiation by brain-derived neurotrophic factor. J Neurosci 24:5151-5161. CrossRef Medline

Kramár EA, Lin B, Rex CS, Gall CM, Lynch G (2006) Integrin-driven actin polymerization consolidates long-term potentiation. Proc Natl Acad Sci U S A 103:5579-5584. CrossRef Medline

Kramár EA, Chen LY, Brandon NJ, Rex CS, Liu F, Gall CM, Lynch G (2009) Cytoskeletal changes underlie estrogen's acute effects on synaptic transmission and plasticity. J Neurosci 29:12982-12993. CrossRef Medline

Kuiper GG, Carlsson B, Grandien K, Enmark E, Häggblad J, Nilsson S, Gustafsson JA (1997) Comparison of the ligand binding specificity and transcript tissue distribution of estrogen receptors $\alpha$ and $\beta$. Endocrinology 138:863-870. CrossRef Medline

Kumar A, Bean LA, Rani A, Jackson T, Foster TC (2015) Contribution of estrogen receptor subtypes, ER $\alpha, \mathrm{ER} \beta$, and GPER1 in rapid estradiolmediated enhancement of hippocampal synaptic transmission in mice. Hippocampus 25:1556-1566. CrossRef Medline

Labouesse MA, Langhans W, Meyer U (2015) Effects of selective estrogen receptor $\alpha$ and $\beta$ modulators on prepulse inhibition in male mice. Psychopharmacology (Berl) 232:2981-2994. CrossRef Medline

Larson J, Lynch G (1986) Induction of synaptic potentiation in hippocampus by patterned stimulation involves two events. Science 232:985-988. CrossRef Medline

Larson J, Wong D, Lynch G (1986) Patterned stimulation at the theta frequency is optimal for the induction of hippocampal long-term potentiation. Brain Res 368:347-350. CrossRef Medline

Larson J, Xiao P, Lynch G (1993) Reversal of LTP by theta frequency stimulation. Brain Res 600:97-102. CrossRef Medline

Lauterborn JC, Palmer LC, Jia Y, Pham DT, Hou B, Wang W, Trieu BH, Cox CD, Kantorovich S, Gall CM, Lynch G (2016) Chronic ampakine treatments stimulate dendritic growth and promote learning in middle-aged rats. J Neurosci 36:1636-1646. CrossRef Medline

Lauterborn JC, Kramár EA, Rice JD, Babayan AH, Cox CD, Karsten CA, Gall CM, Lynch G (2017) Cofilin activation is temporally associated with the cessation of growth in the developing hippocampus. Cereb Cortex 27: 2640-2651. CrossRef Medline

Levin ER, Hammes SR (2016) Nuclear receptors outside the nucleus: extranuclear signalling by steroid receptors. Nat Rev Mol Cell Biol 17:783797. CrossRef Medline 
Li XM, Yang Q, Li XB, Cheng Q, Zhang K, Han J, Zhao JN, Liu G, Zhao MG (2017) Estrogen-like neuroprotection of isopsoralen against spinal cord injury through estrogen receptor ER $\alpha$. Metab Brain Dis 32:259-265. CrossRef Medline

Lu YM, Roder JC, Davidow J, Salter MW (1998) Src activation in the induction of long-term potentiation in CA1 hippocampal neurons. Science 279:1363-1367. CrossRef Medline

Luine VN (2014) Estradiol and cognitive function: past, present and future. Horm Behav 66:602-618. CrossRef Medline

Lynch G, Gall CM (2013) Mechanism based approaches for rescuing and enhancing cognition. Front Neurosci 7:143. CrossRef Medline

Lynch G, Kramár EA, Babayan AH, Rumbaugh G, Gall CM (2013) Differences between synaptic plasticity thresholds result in new timing rules for maximizing long-term potentiation. Neuropharmacology 64:27-36. CrossRef Medline

MacDonald JF, Jackson MF, Beazely MA (2006) Hippocampal long-term synaptic plasticity and signal amplification of NMDA receptors. Crit Rev Neurobiol 18:71-84. CrossRef Medline

McLean AC, Valenzuela N, Fai S, Bennett SA (2012) Performing vaginal lavage, crystal violet staining, and vaginal cytological evaluation for mouse estrous cycle staging identification. J Vis $\operatorname{Exp}(67):$ e4389. CrossRef Medline

Meitzen J, Britson KA, Tuomela K, Mermelstein PG (2017) The expression of select genes necessary for membrane-associated estrogen receptor signaling differ by sex in adult rat hippocampus. Steroids. Advance online publication. Retrieved July 31, 2018. doi:10.1016/j.steroids.2017.09.012. CrossRef Medline

Meng R, Tang HY, Westfall J, London D, Cao JH, Mousa SA, Luidens M, Hercbergs A, Davis FB, Davis PJ, Lin HY (2011) Crosstalk between integrin alphavbeta3 and estrogen receptor-alpha is involved in thyroid hormone-induced proliferation in human lung carcinoma cells. PLoS One 6:e27547. CrossRef Medline

Micevych PE, Mermelstein PG, Sinchak K (2017) Estradiol membraneinitiated signaling in the brain mediates reproduction. Trends Neurosci 40:654-666. CrossRef Medline

Milner TA, McEwen BS, Hayashi S, Li CJ, Reagan LP, Alves SE (2001) Ultrastructural evidence that hippocampal alpha estrogen receptors are located at extranuclear sites. J Comp Neurol 429:355-371. CrossRef Medline

Minichiello L (2009) TrkB signalling pathways in LTP and learning. Nat Rev Neurosci 10:850-860. CrossRef Medline

Mitterling KL, Spencer JL, Dziedzic N, Shenoy S, McCarthy K, Waters EM, McEwen BS, Milner TA (2010) Cellular and subcellular localization of estrogen and progestin receptor immunoreactivities in the mouse hippocampus. J Comp Neurol 518:2729-2743. CrossRef Medline

Mukai H, Kimoto T, Hojo Y, Kawato S, Murakami G, Higo S, Hatanaka Y, Ogiue-Ikeda M (2010) Modulation of synaptic plasticity by brain estrogen in the hippocampus. Biochim Biophys Acta 1800:1030-1044. CrossRef Medline

Munger JS, Sheppard D (2011) Cross talk among TGF- $\beta$ signaling pathways, integrins, and the extracellular matrix. Cold Spring Harb Perspect Biol 3:a005017. CrossRef Medline

Oberlander JG, Woolley CS (2016) 17 $\beta$-estradiol acutely potentiates glutamatergic synaptic transmission in the hippocampus through distinct mechanisms in males and females. J Neurosci 36:2677-2690. CrossRef Medline

Ooishi Y, Kawato S, Hojo Y, Hatanaka Y, Higo S, Murakami G, Komatsuzaki Y, Ogiue-Ikeda M, Kimoto T, Mukai H (2012) Modulation of synaptic plasticity in the hippocampus by hippocampus-derived estrogen and androgen. J Steroid Biochem Mol Biol 131:37-51. CrossRef Medline

Otto T, Eichenbaum H, Wiener SI, Wible CG (1991) Learning-related patterns of CA1 spike trains parallel stimulation parameters optimal for inducing hippocampal long-term potentiation. Hippocampus 1:181192. CrossRef Medline

Patterson MA, Szatmari EM, Yasuda R (2010) AMPA receptors are exocytosed in stimulated spines and adjacent dendrites in a ras-ERK-dependent manner during long-term potentiation. Proc Natl Acad Sci U S A 107: 15951-15956. CrossRef Medline

Pedram A, Razandi M, O’Mahony F, Harvey H, Harvey BJ, Levin ER (2013) Estrogen reduces lipid content in the liver exclusively from membrane receptor signaling. Sci Signal 6:ra36. CrossRef Medline

Pedram A, Razandi M, Lewis M, Hammes S, Levin ER (2014) Membrane- localized estrogen receptor $\alpha$ is required for normal organ development and function. Dev Cell 29:482-490. CrossRef Medline

Perkins MS, Louw-du Toit R, Africander D (2017) A comparative characterization of estrogens used in hormone therapy via estrogen receptor (ER)-alpha and -beta. J Steroid Biochem Mol Biol 174:27-39. CrossRef Medline

Petersen JD, Chen X, Vinade L, Dosemeci A, Lisman JE, Reese TS (2003) Distribution of postsynaptic density (PSD)-95 and $\mathrm{Ca}^{2+} /$ calmodulindependent protein kinase II at the PSD. J Neurosci 23:11270-11278. CrossRef Medline

Rex CS, Lin CY, Kramár EA, Chen LY, Gall CM, Lynch G (2007) Brainderived neurotrophic factor promotes long-term potentiation-related cytoskeletal changes in adult hippocampus. J Neurosci 27:3017-3029. CrossRef Medline

Rex CS, Chen LY, Sharma A, Liu J, Babayan AH, Gall CM, Lynch G (2009) Different rho GTPase-dependent signaling pathways initiate sequential steps in the consolidation of long-term potentiation. J Cell Biol 186:8597. CrossRef Medline

Roepke TA, Ronnekleiv OK, Kelly MJ (2011) Physiological consequences of membrane-initiated estrogen signaling in the brain. Front Biosci (Landmark Ed) 16:1560-1573. Medline

Rudy JW (2015) Actin dynamics and the evolution of the memory trace. Brain Res 1621:17-28. CrossRef Medline

Salter MW, Kalia LV (2004) Src kinases: a hub for NMDA receptor regulation. Nat Rev Neurosci 5:317-328. CrossRef Medline

Scharfman HE, MacLusky NJ (2008) Estrogen-growth factor interactions and their contributions to neurological disorders. Headache 48 [Suppl. 2]:S77-S89. CrossRef Medline

Seese RR, Babayan AH, Katz AM, Cox CD, Lauterborn JC, Lynch G, Gall CM (2012) LTP induction translocates cortactin at distant synapses in wildtype but not Fmr1 knock-out mice. J Neurosci 32:7403-7413. CrossRef Medline

Seese RR, Chen LY, Cox CD, Schulz D, Babayan AH, Bunney WE, Henn FA, Gall CM, Lynch G (2013) Synaptic abnormalities in the infralimbic cortex of a model of congenital depression. J Neurosci 33:13441-13448. CrossRef Medline

Seese RR, Wang K, Yao YQ, Lynch G, Gall CM (2014) Spaced training rescues memory and ERK1/2 signaling in fragile $\mathrm{X}$ syndrome model mice. Proc Natl Acad Sci U S A 111:16907-16912. CrossRef Medline

Smejkalova T, Woolley CS (2010) Estradiol acutely potentiates hippocampal excitatory synaptic transmission through a presynaptic mechanism. J Neurosci 30:16137-16148. CrossRef Medline

Song RX, Zhang Z, Santen RJ (2005) Estrogen rapid action via protein complex formation involving ER $\alpha$ and src. Trends Endocrinol Metab 16:347353. CrossRef Medline

Sweatt JD (2001) The neuronal MAP kinase cascade: a biochemical signal integration system subserving synaptic plasticity and memory. J Neurochem 76:1-10. CrossRef Medline

Tabatadze N, Sato SM, Woolley CS (2014) Quantitative analysis of longform aromatase mRNA in the male and female rat brain. PLoS One 9:e100628. CrossRef Medline

Trepanier CH, Jackson MF, MacDonald JF (2012) Regulation of NMDA receptors by the tyrosine kinase fyn. FEBS J 279:12-19. CrossRef Medline

Trieu BH, Kramár EA, Cox CD, Jia Y, Wang W, Gall CM, Lynch G (2015) Pronounced differences in signal processing and synaptic plasticity between piriform-hippocampal network stages: a prominent role for adenosine. J Physiol 593:2889-2907. CrossRef Medline

Vierk R, Glassmeier G, Zhou L, Brandt N, Fester L, Dudzinski D, Wilkars W, Bender RA, Lewerenz M, Gloger S, Graser L, Schwarz J, Rune GM (2012) Aromatase inhibition abolishes LTP generation in female but not in male mice. J Neurosci 32:8116-8126. CrossRef Medline

Wang JQ, Fibuch EE, Mao L (2007) Regulation of mitogen-activated protein kinases by glutamate receptors. J Neurochem 100:1-11. CrossRef Medline

Wang W, Kantorovich S, Babayan AH, Hou B, Gall CM, Lynch G (2016a) Estrogen's effects on excitatory synaptic transmission entail integrin and TrkB transactivation and depend upon $\beta 1$-integrin function. Neuropsychopharmacology 41:2723-2732. CrossRef Medline

Wang W, Trieu BH, Palmer LC, Jia Y, Pham DT, Jung KM, Karsten CA, Merrill CB, Mackie K, Gall CM, Piomelli D, Lynch G (2016b) A primary cortical input to hippocampus expresses a pathway-specific and 
endocannabinoid-dependent form of long-term potentiation. eNeuro 3:ENEURO.0160-16.2016. CrossRef Medline

Wang W, Jia Y, Pham DT, Palmer LC, Jung KM, Cox CD, Rumbaugh G, Piomelli D, Gall CM, Lynch G (2018) Atypical endocannabinoid signaling initiates a new form of memory-related plasticity at a cortical input to hippocampus. Cereb Cortex 28:2253-2266. CrossRef Medline

Wang XB, Bozdagi O, Nikitczuk JS, Zhai ZW, Zhou Q, Huntley GW (2008) Extracellular proteolysis by matrix metalloproteinase-9 drives dendritic spine enlargement and long-term potentiation coordinately. Proc Natl Acad Sci U S A 105:19520-19525. CrossRef Medline

Waters EM, Thompson LI, Patel P, Gonzales AD, Ye HZ, Filardo EJ, Clegg DJ, Gorecka J, Akama KT, McEwen BS, Milner TA (2015) G-proteincoupled estrogen receptor 1 is anatomically positioned to modulate synaptic plasticity in the mouse hippocampus. J Neurosci 35:2384-2397. CrossRef Medline

Wei J, Yuen EY, Liu W, Li X, Zhong P, Karatsoreos IN, McEwen BS, Yan Z (2014) Estrogen protects against the detrimental effects of repeated stress on glutamatergic transmission and cognition. Mol Psychiatry 19:588598. CrossRef Medline

Weiland NG, Orikasa C, Hayashi S, McEwen BS (1997) Distribution and hormone regulation of estrogen receptor immunoreactive cells in the hippocampus of male and female rats. J Comp Neurol 388:603-612. CrossRef Medline

Weilinger NL, Lohman AW, Rakai BD, Ma EM, Bialecki J, Maslieieva V, Rilea T, Bandet MV, Ikuta NT, Scott L, Colicos MA, Teskey GC, Winship IR, Thompson RJ (2016) Metabotropic NMDA receptor signaling couples src family kinases to pannexin-1 during excitotoxicity. Nat Neurosci 19: 432-442. CrossRef Medline

Woolley CS (2007) Acute effects of estrogen on neuronal physiology. Annu Rev Pharmacol Toxicol 47:657-680. CrossRef Medline

Yamazaki Y, Jia Y, Wong JK, Sumikawa K (2006) Chronic nicotine-induced switch in src-family kinase signaling for long-term potentiation induction in hippocampal CA1 pyramidal cells. Eur J Neurosci 24:3271-3284. CrossRef Medline

Zhang JC, Yao W, Dong C, Yang C, Ren Q, Ma M, Han M, Hashimoto K (2015) Comparison of ketamine, 7,8-dihydroxyflavone, and ANA-12 antidepressant effects in the social defeat stress model of depression. Psychopharmacology (Berl) 232:4325-4335. CrossRef Medline

Zuloaga DG, Zuloaga KL, Hinds LR, Carbone DL, Handa RJ (2014) Estrogen receptor beta expression in the mouse forebrain: age and sex differences. J Comp Neurol 522:358-371. CrossRef Medline 